$9-15-2015$

Comparison of surface chlorophyll, primary production, and satellite imagery in hydrographically different sounds off southern New England

Lindsey Fields

Jeffrey Mercer

Kimberly Hyde

Mark Brush

et al

Follow this and additional works at: https://scholarworks.wm.edu/vimsarticles

Part of the Marine Biology Commons 


\title{
Comparison of surface chlorophyll, primary production, and satellite imagery in hydrographically different sounds off southern New England
}

\author{
Lindsey Fields ${ }^{1,5, *}$, Jeffrey Mercer ${ }^{1}$, Kimberly J. W. Hyde ${ }^{2}$, Mark Brush ${ }^{3}$, \\ Scott W. Nixon ${ }^{1}$, Candace Oviatt ${ }^{1}$, Malia L. Schwartz ${ }^{4}$, David Ullman ${ }^{1}$, Daniel Codiga ${ }^{1}$ \\ ${ }^{1}$ Graduate School of Oceanography, University of Rhode Island, Narragansett, RI 02882, USA \\ ${ }^{2}$ NOAA/NMFS, Narragansett, RI 02882, USA \\ ${ }^{3}$ Virginia Institute of Marine Science, College of William \& Mary, PO Box 1346, Gloucester Point, VA 23062, USA \\ ${ }^{4}$ University of Rhode Island, Kingston, RI 02881, USA \\ ${ }^{5}$ Present address: Department of Marine Sciences, University of Georgia, 325 Sanford Drive, Athens, GA 30602, USA
}

\begin{abstract}
Block Island Sound (BIS) and Rhode Island Sound (RIS) are adjacent inner continental shelf ecosystems with contrasting hydrographic regimes. BIS exhibits more energetic tidal mixing, and water column stratification remains weak but persists year-round due to nearby estuarine exchange flow; RIS is less influenced by estuaries, and more seasonal with strong stratification in summer. We compared annual cycles of phytoplankton biomass and primary production in BIS and RIS using measurements (surface chlorophyll, ${ }^{14} \mathrm{C}$ primary production), primary production models (Webb/Platt and BZE models), and satellite ocean color products. During 22 mo of sampling, measured surface chlorophyll was not significantly different between BIS (mean = $1.86 \mathrm{mg} \mathrm{m}^{-3}$ ) and RIS $\left(1.69 \mathrm{mg} \mathrm{m}^{-3}\right)$, and bimodal peaks of phytoplankton biomass and production occurred concurrently in both Sounds. In contrast, a 12 yr ocean-color based chlorophyll time series indicated higher long-term average surface chlorophyll in the more well-mixed system (BIS, mean $=1.50 \mathrm{mg} \mathrm{m}^{-3}$; RIS, mean $=0.86 \mathrm{mg} \mathrm{m}^{-3}$ ). BIS annual primary production (318 to $329 \mathrm{~g}$ $\mathrm{C} \mathrm{m}^{-2} \mathrm{yr}^{-1}$ ) was higher than RIS (239 to $256 \mathrm{~g} \mathrm{C} \mathrm{m}^{-2} \mathrm{yr}^{-1} ; \mathrm{p}<0.001$ ). These differences were most apparent during the summer, concurrent with the largest differences in water column stratification. Phytoplankton bloom phenology was driven by physical processes, with chlorophyll significantly related to water column stratification $(\mathrm{r}=-0.51, \mathrm{p}=0.01)$, depth of the euphotic zone $(\mathrm{r}=$ $-0.54, \mathrm{p}=0.05)$, and surface water salinity $(\mathrm{r}=0.54, \mathrm{p}=0.04)$. Primary production was correlated with surface water temperature $(\mathrm{r}=0.57, \mathrm{p}=0.03)$ but the mechanisms underlying production differences between the Sounds remain unresolved. We hypothesize that different hydrographies give rise to different productivity between the Sounds.
\end{abstract}

KEY WORDS: Chlorophyll $a \cdot$ Primary production $\cdot$ Continental shelf $\cdot$ Stratification $\cdot$ Remote sensing $\cdot$ Empirical model

\section{INTRODUCTION}

The continental shelf occupies less than $10 \%$ of the area of the open ocean, yet it accounts for a considerable amount of primary production relative to its size (Smith \& Hollibaugh 1993). Roughly 10 to $33 \%$ of oceanic primary production (Walsh 1988, Knauer 1993, Smith \& Hollibaugh 1993, Longhurst 1995, MullerKarger et al. 2005) and 5 to $10 \%$ of global primary production (Walsh 1988) occurs on the continental margin. These areas are also 'hot spots' for biogeochemical processes and play important roles in 
global nutrient cycles (Christensen et al. 1987, Smith \& Hollibaugh 1993, Seitzinger et al. 2002, MullerKarger et al. 2005). The relatively high rates of primary production, physical energy inputs (e.g. tidal and wind energy), and input of organic material from land that are typical of these boundary ecosystems often translate into areas with thriving fisheries of local economic importance (Nixon 1988, Smith \& Hollibaugh 1993, Nixon \& Buckley 2002). This is certainly the case for the continental shelf of the northwest Atlantic Ocean. The area from the Gulf of Maine to Cape Hatteras, NC, is one of the most productive shelf ecosystems in the world. The fishing industry there has provided income to the nearby coastal states since the late $17^{\text {th }}$ century, and is currently producing profits of at least 1 billion dollars per year (Sherman et al. 1996, Costanza et al. 1997, Hall et al. 2008).

Phytoplankton form the base of the food chain in most marine ecosystems, and understanding the drivers and dynamics of their productivity is essential to understanding ecosystem function and variability. The physics of the ocean, in large part, drive the patterns of plankton phenology (Banse 1994), though this relationship is far less straightforward in coastal ecosystems compared to the open ocean. Nutrient availability is typically high in coastal marine ecosystems because of allochthonous inputs and autochthonous remineralization in the water column and benthos; benthic remineralization typically supplies a large portion of the nutrients that fuel water column production (Nixon 1981). However, water column stratification fosters exhaustion of nutrients in the surface waters by limiting the addition of nutrients above the pycnocline, and primary production can decrease as phytoplankton deplete the nutrient supply (Taft et al. 1980). In this respect, stratification can play a critical role in regulating the overall productivity of an ecosystem.

Many studies have examined the influence of mixing and/or water column stratification on phytoplankton dynamics in single coastal ecosystems over different timescales (e.g. mixing events and across annual cycles; Malone et al. 1986, Cushing 1989, Townsend et al. 1992, Koseff et al. 1993, Doyon et al. 2000, Holliday et al. 2006). Here, we simultaneously measured differences in phytoplankton dynamics between 2 adjacent ecosystems with contrasting hydrographic regimes across an annual cycle. Our objective was to compare annual cycles of phytoplankton biomass and primary production between 2 adjacent inner continental shelf ecosystems that are characterized by different hydrographic regimes using a combina- tion of measurements, primary production models, and ocean color satellite data. We measured annual cycles of chlorophyll a $(\mathrm{chl} a)$, primary production, and physical characteristics of the water column throughout Block Island and Rhode Island Sounds, Rhode Island, USA. To further inform our comparison between the Sounds, we expanded our dataset over space and time by (1) validating SeaWiFs satellite chl a data with our measurements, and using satellite ocean color products to extrapolate across a $10 \mathrm{yr}$ period of time in our study areas, and (2) using our primary production measurements and ancillary data to construct models of daily primary production.

\section{MATERIALS AND METHODS}

\section{Study area}

Block Island Sound (BIS) and Rhode Island Sound (RIS) are adjacent ecosystems on the inner continental shelf of southern New England (northwest Atlantic Ocean). They are both open-water, phytoplankton-based systems that are dynamically connected to Narragansett Bay, Buzzards Bay, Long Island Sound, Vineyard Sound, and the Atlantic Ocean. RIS transitions into BIS in the area west of Block Island, RI (Fig. 1). Despite their similar mean depths $(\sim 30 \mathrm{~m})$, BIS and RIS have different hydrographic regimes that make for an interesting comparison. BIS exhibits cooler surface waters during summer and a relatively more well-mixed water column as a result of strong tidal mixing, while RIS has warmer surface waters and is vertically stratified during the summer (Shonting \& Cook 1970, Codiga \& Ullman 2010). For comparisons between BIS and RIS, we assigned study area boundaries that were based on contours of mean annual surface water temperature between the Sounds (Fig. 1a).

\section{Characterization of hydrography}

A hydrographic grid survey was conducted throughout BIS and RIS across an annual cycle from September 2009 to December 2010. Four vessel-based surveys of 48 stations were conducted at the beginning of each season across a 2 to $3 \mathrm{~d}$ period. Vertical profiles of electrical conductivity, temperature, pressure, dissolved oxygen concentration, chlorophyll fluorescence, turbidity, and photosynthetically active radiation (PAR) were obtained with a hand-lowered package at each station. Profiles were taken using a SeaBird 


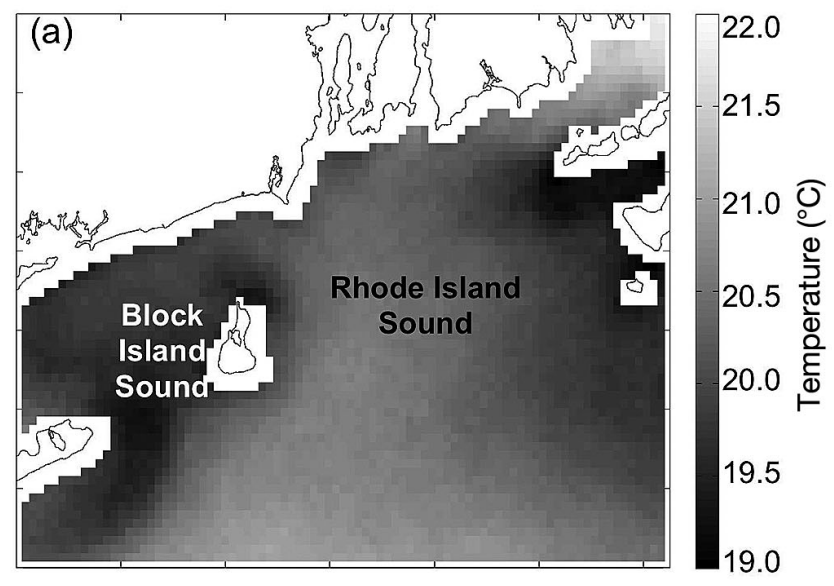

Fig. 1. (a) MODIS satellite mean summer (July to September) sea surface temperature image of Block Island Sound (BIS) and Rhode Island Sound (RIS) for 2002 to 2007. Note the warmer surface water in seasonally stratified RIS compared with the cooler, more well-mixed BIS. (b) Study area boundaries used for this study, shown with surface chl a and primary production sampling stations

Electronics SBS 19plus CTD, a Turner Designs SCUFA 2000-007 Fluorometer, and a BioSpherical QSP2300 PAR sensor. CTD casts were also made at our $2{ }^{14} \mathrm{C}$ primary production sampling stations (see ${ }^{114} \mathrm{C}$ Primary production' below) during each trip for water sample collection. CTD data were processed using SBE data processing software, and salinity was calculated from the measured conductivity, temperature, and pressure data (for detailed results from the grid survey, see Ullman \& Codiga 2010). Measurements were used to construct a temperature and salinity record for the 2 primary production sampling stations. Hydrographic characteristics on days in between CTD casts were interpolated using the Natural Neighbor method with Delaunay triangulation (Lee \& Schachter 1980, Watson 1992, 1994).

\section{Surface chl a}

Surface water samples were collected throughout the study areas from December 2008 to September 2010 during cruises of opportunity by laboratory personnel, local fishermen, and other assisting scientists. Bucket samples were collected, transferred into

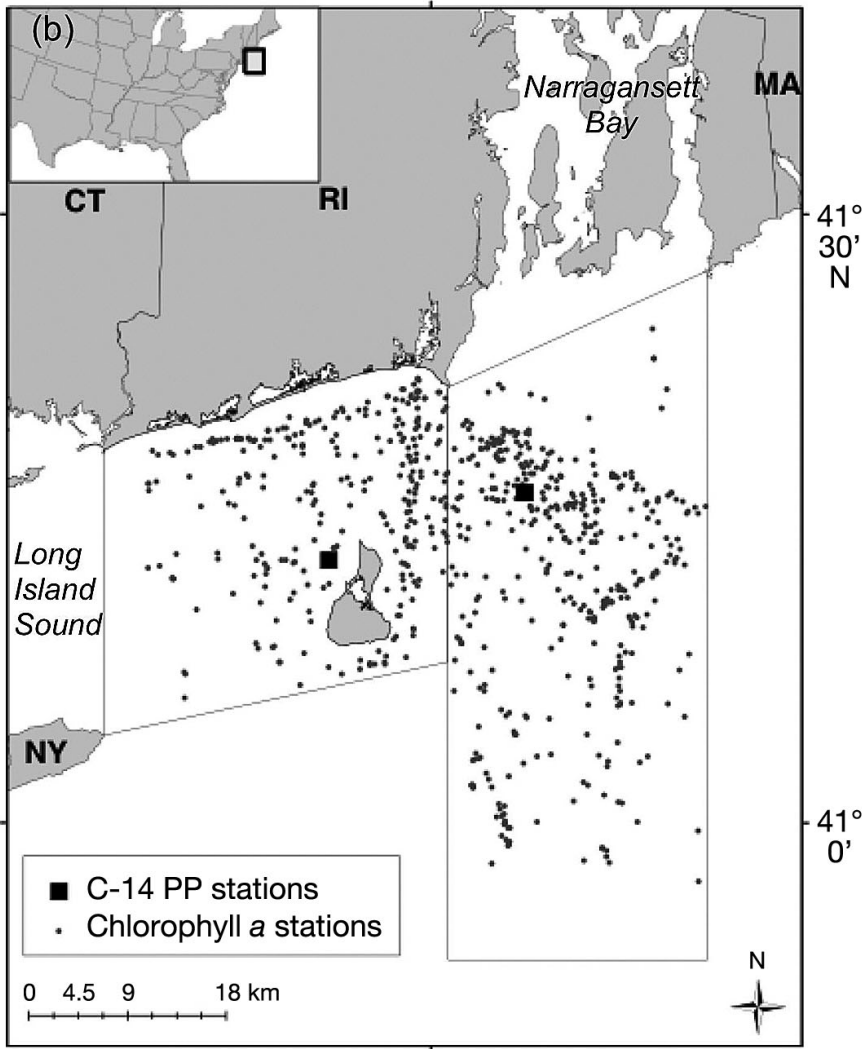

$71^{\circ} 30^{\prime} \mathrm{W}$

opaque polypropylene bottles, and kept in a cooler on ice during transport. The time between water collection and laboratory analysis varied due to circumstance, but typically was less than $5 \mathrm{~h}$. Because samples were collected during cruises of opportunity, they were not collected at regular time intervals or at fixed locations (Fig. 1b). Metadata were recorded for each sample. Surface chl a concentrations from each station were measured in triplicate by immediate extraction on $0.7 \mu \mathrm{m}$ Whatman GF/F filters $(100 \mathrm{ml}$ sample) in $90 \%$ acetone (Mantoura et al. 1996, Arar \& Collins 1997, Graff \& Rynearson 2011). Samples were analyzed on a Turner 10AU fluorometer, and mean chl $a$ and phaeopigment concentrations were calculated from the triplicate samples measured at each station.

\section{Validation of SeaWiFs chl a}

Individual daily merged local area coverage (MLAC) SeaWiFS images were mapped at $1 \mathrm{~km}$ pixel resolution for the southern New England coast using a cylindrical map projection. The standard SeaWiFS chl a (CHL_OC4) and remote sensing reflectance 
$\left(R_{\mathrm{rS}}\right)$ products were derived using SeaDAS 6.2 (R2010, http://oceancolor.gsfc.nasa.gov/). A second chl a product was calculated using a regional algorithm developed by Pan et al. $(2008,2010)$ for the Mid-Atlantic Bight (an inner shelf ecosystem located just south of our study area). Around the coordinates of each in situ sampling station, a $3 \times 3$ pixel array was extracted from the satellite images captured within $6 \mathrm{~h}$ of water sample collection. Standard validation procedures recommend a comparison window of $\pm 3 \mathrm{~h}$ (Bailey \& Werdell 2006); however, due to the opportunistic nature of the in situ sampling, we expanded the time window to $\pm 6 \mathrm{~h}$ to increase the number of potential comparisons. The geometric means of satellite-derived chlorophyll arrays with 5 or more valid (cloud-free) pixels were calculated and compared to the in situ chl a samples. The geometric mean was used because chl a concentrations are commonly lognormally distributed, and the geometric mean reduces the influence of a small number of high or low values (outliers) on the mean compared to the arithmetic mean (Campbell 1995, Bricaud et al. 2002, Yoder et al. 2002, Yoder \& Kennelly 2003). A 12 yr time series (1998 to 2010) of SeaWiFS surface chlorophyll was constructed for BIS and RIS using the Pan et al. $(2008,2010)$ regional chlorophyll algorithm.

\section{${ }^{14} \mathrm{C}$ primary production}

Two stations were sampled for carbon-14 $\left({ }^{14} \mathrm{C}\right)$ primary production measurements, one in BIS and one in RIS (Fig. 1b). Stations were sampled 14 times

Table 1. Definitions of ${ }^{14} \mathrm{C}$ primary production model variables

\begin{tabular}{|c|c|c|c|}
\hline $\begin{array}{l}\text { Para- } \\
\text { meter }\end{array}$ & Units & Model(s) & Description \\
\hline$E_{\mathrm{o}}$ & $E \mathrm{~m}^{-2} \mathrm{~d}^{-1}$ & $\begin{array}{l}\text { Webb/Platt, } \\
\text { BZE }\end{array}$ & $\begin{array}{l}\text { Ambient photosynthetically } \\
\text { active radiation (PAR) }\end{array}$ \\
\hline$Z_{\mathrm{p}}$ & $\mathrm{m}$ & BZE & $\begin{array}{l}\text { Depth of photic zone (1\% light } \\
\text { level) }\end{array}$ \\
\hline$k$ & $\mathrm{~m}^{-1}$ & $\begin{array}{l}\text { Webb/Platt, } \\
\text { BZE }\end{array}$ & Light attenuation coefficient \\
\hline$\alpha$ & $\mathrm{mg} \mathrm{C} \mu \mathrm{E} \mathrm{m} \mathrm{m}^{-1}$ & Webb/Platt & $\begin{array}{l}\text { Initial slope of the production- } \\
\text { irradiance curve }\end{array}$ \\
\hline$\beta$ & $\mathrm{mg} \mathrm{C} \mu \mathrm{E} \mathrm{m} \mathrm{m}^{-1}$ & Webb/Platt & Degree of photoinhibition \\
\hline$P_{\max }$ & $\mathrm{mg} \mathrm{C} \mathrm{m}{ }^{-3} \mathrm{~h}^{-1}$ & Webb/Platt & $\begin{array}{l}\text { Light-saturated rate of } \\
\text { production (Webb equation) }\end{array}$ \\
\hline$P_{\mathrm{s}}$ & $\mathrm{mgC} \mathrm{m} \mathrm{m}^{-3} \mathrm{~h}^{-1}$ & Webb/Platt & $\begin{array}{l}\text { Theoretical value of } P_{\max } \text { in } \\
\text { the absence of photoinhibition } \\
\text { (Platt equation) }\end{array}$ \\
\hline$B$ & $\mu g l^{-3}$ & BZE & $\begin{array}{l}\text { Phytoplankton biomass } \\
\text { measured as chl a }\end{array}$ \\
\hline$P_{\mathrm{d}}$ & $\mathrm{gC} \mathrm{m}^{-2} \mathrm{~d}^{-1}$ & $\begin{array}{l}\text { Webb/Platt, } \\
\text { BZE }\end{array}$ & $\begin{array}{l}\text { Daily areal photic zone primary } \\
\text { productivity }\end{array}$ \\
\hline
\end{tabular}

(approximately monthly) throughout 2010 (see Table 2). Water samples were collected with a Niskin bottle $1 \mathrm{~m}$ below the surface, filtered through a $300 \mu \mathrm{m}$ mesh screen (to remove mesozooplankton) into opaque $1 \mathrm{l}$ polyethylene bottles, and maintained at near-ambient temperature during transportation to the laboratory $(<6 \mathrm{~h})$. While on station, surface chl $a$ samples were collected (see methods above), and a CTD profile was taken using a SeaBird CTD equipped with a Biospherical Scalar PAR sensor.

Primary production was measured on the same day as sample collection immediately upon return to the laboratory using a small volume/short incubation time method (Lewis \& Smith 1983, Smith 2011) and standard ${ }^{14} \mathrm{C}$ procedures (Strickland \& Parsons 1972) following Oviatt et al. (2007). For each water sample collected, a series of 18 incubation vials were prepared (16 light and 2 dark) to be incubated at a range of different light intensities between 0 and $2000 \mu \mathrm{E} \mathrm{m}^{-2} \mathrm{~s}^{-1}$. Vials of $5 \mathrm{ml}$ sample plus $100 \mu \mathrm{l}$ of $10 \mu \mathrm{Ci} \mathrm{ml}{ }^{-1}{ }^{14} \mathrm{C}$ stock solution were incubated for $2 \mathrm{~h}$ within $2^{\circ} \mathrm{C}$ of in situ temperature. Upon removal from the incubator, $200 \mu \mathrm{l}$ of $0.10 \mathrm{~N}$ $\mathrm{HCl}$ was added to each vial, mixed, and gently agitated uncapped in the dark for $\sim 40 \mathrm{~h}$ to allow all of the unincorporated ${ }^{14} \mathrm{C}$ to be converted to $\mathrm{CO}_{2}$ gas and removed from the sample. Measurements of ${ }^{14} \mathrm{C}$ converted into organic carbon were made on a Packard TriCarb Liquid Scintillation Counter (Model 2900), and dissolved inorganic carbon was determined by acidifying samples and measuring carbon dioxide released using an O.I. Analytical 1010 total carbon analyzer.

In the majority of cases, we measured photoinhibition and used the equation $P_{\mathrm{d}}=P_{\mathrm{s}}\left(1-\mathrm{e}^{-\alpha}\right) \mathrm{e}^{-\beta}$ (Platt et al. 1980) to fit hourly incubation photosynthesis-irradiance $(P-E)$ curves to obtain volume-specific primary production (variables and their units are defined in Table 1). On 4 occasions (2 at each station), we did not measure photoinhibition, and fit $P-E$ curves using the equation $P_{\mathrm{d}}=P_{\max }(1-$ $e^{-\alpha}$ ) (Webb et al. 1974) (Table 2). P-E curves were integrated through the water column to the euphotic depth $\left(Z_{\mathrm{p}}\right)$ in $1 \mathrm{~m}$ increments using measured extinction coefficients and hourly irradiance data (measurements of total solar radiation made every $15 \mathrm{~min}$ at a nearby weather station in Kingston, RI; National Climatic Data Center, 
Table 2. Values of each model variable measured during ${ }^{14} \mathrm{C}$ primary production incubations. See Table 1 for definitions of model parameters. Dates are given as mm/dd/yyyy; BIS: Block Island Sound; RIS: Rhode Island Sound; n/a: not applicable

\begin{tabular}{|c|c|c|c|c|c|c|c|c|}
\hline & \multicolumn{8}{|c|}{-Parameter } \\
\hline & $E_{\mathrm{o}}$ & $Z_{\mathrm{p}}$ & $k$ & $\alpha$ & $\beta$ & $P_{\max }$ & $P_{\mathrm{s}}$ & $B$ \\
\hline \multicolumn{9}{|l|}{ 01/19/2010 } \\
\hline BIS & 1.35 & 16.8 & 0.27 & 0.1 & 0.023 & n/a & 29.59 & 5.97 \\
\hline RIS & & 15.69 & 0.29 & 0.15 & 0.002 & $\mathrm{n} / \mathrm{a}$ & 14.83 & 6.07 \\
\hline \multicolumn{9}{|l|}{ 02/05/2010 } \\
\hline BIS & 21.91 & 13.78 & 0.33 & 0.1 & 0.007 & $\mathrm{n} / \mathrm{a}$ & 14.51 & 5.03 \\
\hline RIS & & 16.64 & 0.28 & 0.07 & 0.001 & $\mathrm{n} / \mathrm{a}$ & 12.2 & 4.3 \\
\hline \multicolumn{9}{|l|}{ 03/10/2010 } \\
\hline BIS & 35.8 & 24.35 & 0.19 & 0.01 & 0.003 & $\mathrm{n} / \mathrm{a}$ & 3.82 & 1.4 \\
\hline RIS & & 24.21 & 0.19 & 0.02 & $\mathrm{n} / \mathrm{a}$ & 2.56 & $\mathrm{n} / \mathrm{a}$ & 1.31 \\
\hline \multicolumn{9}{|l|}{ 04/14/2010 } \\
\hline BIS & 52.38 & 22.19 & 0.21 & 0.02 & $\mathrm{n} / \mathrm{a}$ & 5.58 & $\mathrm{n} / \mathrm{a}$ & 1.33 \\
\hline RIS & & 24.75 & 0.19 & 0.02 & $<0.001$ & $\mathrm{n} / \mathrm{a}$ & 2.73 & 0.88 \\
\hline \multicolumn{9}{|l|}{ 04/30/2010 } \\
\hline BIS & 54.73 & 21.38 & 0.22 & 0.04 & 0.016 & $\mathrm{n} / \mathrm{a}$ & 22.54 & 2.1 \\
\hline RIS & & 20.96 & 0.22 & 0.03 & $<0.001$ & $\mathrm{n} / \mathrm{a}$ & 2.86 & 0.94 \\
\hline \multicolumn{9}{|l|}{ 05/12/2010 } \\
\hline BIS & 16.38 & 24.24 & 0.19 & 0.02 & 0.002 & $\mathrm{n} / \mathrm{a}$ & 3.76 & 0.24 \\
\hline RIS & & 32.48 & 0.14 & 0.02 & 0.001 & $\mathrm{n} / \mathrm{a}$ & 3.26 & 0.84 \\
\hline \multicolumn{9}{|l|}{ 06/17/2010 } \\
\hline BIS & 41.4 & 17.65 & 0.26 & 0.05 & 0.001 & $\mathrm{n} / \mathrm{a}$ & 8.16 & 0.81 \\
\hline RIS & & 25 & 0.18 & 0.01 & 0.001 & $\mathrm{n} / \mathrm{a}$ & 1.59 & 0.93 \\
\hline \multicolumn{9}{|l|}{ 07/01/2010 } \\
\hline BIS & 51.37 & 20.83 & 0.22 & 0.05 & 0.001 & $\mathrm{n} / \mathrm{a}$ & 9.22 & 1.13 \\
\hline RIS & & 26.27 & 0.18 & 0.03 & $<0.001$ & $\mathrm{n} / \mathrm{a}$ & 4.97 & 0.75 \\
\hline \multicolumn{9}{|l|}{ 07/23/2010 } \\
\hline BIS & 15.82 & 20.45 & 0.23 & 0.04 & 0.002 & $\mathrm{n} / \mathrm{a}$ & 10.34 & 0.85 \\
\hline RIS & & 21 & 0.22 & 0.02 & 0.001 & $\mathrm{n} / \mathrm{a}$ & 5.33 & 1.14 \\
\hline \multicolumn{9}{|l|}{ 08/17/2010 } \\
\hline BIS & 34.04 & 22.14 & 0.21 & 0.13 & 0.014 & $\mathrm{n} / \mathrm{a}$ & 46.57 & 4.62 \\
\hline RIS & & 22.36 & 0.21 & 0.12 & 0.007 & $\mathrm{n} / \mathrm{a}$ & 24.35 & 3.12 \\
\hline \multicolumn{9}{|l|}{ 09/14/2010 } \\
\hline BIS & 38.65 & 18.58 & 0.25 & 0.04 & 0.002 & $\mathrm{n} / \mathrm{a}$ & 11.29 & 1.27 \\
\hline RIS & & 19.84 & 0.23 & 0.04 & 0.001 & $\mathrm{n} / \mathrm{a}$ & 8.88 & 1.3 \\
\hline \multicolumn{9}{|l|}{ 10/13/2010 } \\
\hline BIS & 34.06 & 13.47 & 0.34 & 0.23 & 0.052 & $\mathrm{n} / \mathrm{a}$ & 91.69 & 5.79 \\
\hline RIS & & 14.9 & 0.31 & 0.18 & 0.001 & $\mathrm{n} / \mathrm{a}$ & 29.91 & 3.93 \\
\hline \multicolumn{9}{|l|}{$11 / 29 / 2010$} \\
\hline BIS & 20.15 & 14.46 & 0.32 & 0.02 & $\mathrm{n} / \mathrm{a}$ & 8.34 & $\mathrm{n} / \mathrm{a}$ & 1.96 \\
\hline RIS & & 16.7 & 0.28 & 0.04 & 0.002 & $\mathrm{n} / \mathrm{a}$ & 9.25 & 2.52 \\
\hline \multicolumn{9}{|l|}{$12 / 30 / 2010$} \\
\hline BIS & 18.43 & 13.61 & 0.34 & 0.04 & 0.013 & $\mathrm{n} / \mathrm{a}$ & 16.83 & 2.73 \\
\hline RIS & & 16.13 & 0.29 & 0.04 & $\mathrm{n} / \mathrm{a}$ & 9.36 & $\mathrm{n} / \mathrm{a}$ & 3.8 \\
\hline
\end{tabular}

\section{Models of primary production}

Two different empirical models were used to scale up our monthly ${ }^{14} \mathrm{C}$ measurements and predict daily values of primary production for an annual cycle using ${ }^{14} \mathrm{C}$ measurements described in this study, additional data collected throughout the duration of the project, and supplementary data available from other sources (see Table 1 for description of model parameters).

\section{Webb/Platt model}

The Webb/Platt model entails interpolation of daily areal photic zone productivity $\left(P_{\mathrm{d}}, \mathrm{g} \mathrm{C} \mathrm{m} \mathrm{m}^{-2} \mathrm{~d}^{-1}\right)$ for days in between ${ }^{14} \mathrm{C}$ measurements. ${ }^{14} \mathrm{C}$ productivity rates that were measured and calculated according to the equations listed above (see ${ }^{114} \mathrm{C}$ primary production') were linearly interpolated to daily values for the entire year (2010) from the ${ }^{14} \mathrm{C}$ measurements $(\mathrm{n}=14)$ by calculating a weighted average production rate for each day that took into account both the measurement before and after a given day, with greater influence from the measurement that was closest in time (Oviatt et al. 2007, Smith 2011).

\section{BZE model}

The BZE model is an empirical regression for computing $P_{\mathrm{d}}$ based on the relationship between measured ${ }^{14} \mathrm{C}$ production and the parameter $B Z_{\mathrm{p}} E_{\mathrm{o}}$ (Table 1; Cole \& Cloern 1987). A separate $B Z E$ model was generated for each Sound using the ${ }^{14} \mathrm{C}$ production rates, surface chl a concentration and light attenuation measured in either BIS or RIS, and using daily integrated irradiance measurements from the National Climatic Data Center (Table 2).

www.ncdc.noaa.gov/crn/report) that were converted to $\operatorname{PAR}\left(E_{0}\right)$ assuming $\operatorname{PAR}=0.4363 \times$ Irradiance (Calabretta 2009). Production rates were also integrated through time (each hour of daylight) to obtain daily production estimates.
Once the BZE models were constructed, $P_{\mathrm{d}}$ was calculated for an annual cycle (2010) in BIS and RIS using daily interpolated values of model parameters $\left(B\right.$ and $Z_{\mathrm{p}}$ ) and daily irradiance measurements $\left(E_{\mathrm{o}}\right)$. Surface chl a measurements collected over 22 mo 
(including cruises of opportunity and ${ }^{14} \mathrm{C}$ sampling days) were compiled into 1 annual cycle (month and day) to calculate average values for each day. When more than one chlorophyll sample was collected in each study area (see Fig. 1 for spread of sampling stations), daily arithmetic mean values were computed across all stations within BIS and RIS. Daily surface chl a concentrations $(B)$ were linearly interpolated between the mean values for each day of the year that measurements were made for BIS $(\mathrm{n}=67)$ and RIS (n $=78$; Fig. $2 \mathrm{a}, \mathrm{c}) . Z_{\mathrm{p}}$ was calculated from extrapolated measurements of extinction coefficients $(k)$ using Beer's Law. To extrapolate $k$ between measurements, we used a best fit through data over the annual cycle ( $\mathrm{n}=65$ and 67 for BIS and RIS, respectively). For BIS, a linear fit was used $\left(\mathrm{R}^{2}=0.27\right)$ and although the slope was significantly different from zero ( $p<0.0001)$, the slope was so small that the overall average $k$ value was used for all days in the model to prevent a continuous infinite increase (Fig. 2b). For RIS, a second order polynomial fit was used $\left(\mathrm{R}^{2}=\right.$ 0.45 ) to extrapolate daily $k$ values (Fig. $2 d$ ).

\section{Statistical analysis}

Geometric means of surface chl a values were compared for the entire sampling period and on an annual basis using un-pooled Student's $t$-tests. ${ }^{14} \mathrm{C}$ measured primary production was normalized to biomass (surface chl a values), $P_{\mathrm{d}}^{B}$ in $\mathrm{mg} \mathrm{C} \mathrm{mg}$ chl $a^{-1}$ $\mathrm{d}^{-1}$, and qualitatively compared between BIS and RIS. Linear regression analysis was used to determine how much of the variation in primary production could be attributed to chl a concentrations. A 2-way ANOVA was used to compare average daily modeled primary production between Sounds and empirical models at a significance level of $\mathrm{p}<0.05$. Analyses were performed in JMP Pro 11 (SAS).

Correlation analyses were performed to examine potential relationships between ${ }^{14} \mathrm{C}$-measured primary production, surface chl $a_{1}$ and various environmental characteristics of the 2 Sounds that might provide insight into the mechanisms driving phytoplankton dynamics. These environmental characteristics included CTD measurements of $Z_{\mathrm{p}}$, salinity, temperature, and PAR made at each station on sampling days. Values from $1 \mathrm{~m}$ below the surface were used for each parameter (excluding $Z_{\mathrm{p}}$ ). For each CTD cast, we calculated a value for vertical water column stratification as in Ullman \& Codiga (2010), using the difference in density $(\Delta \rho)$ between deep ( 1 to $3 \mathrm{~m}$ above the bottom) and surface (1 $\mathrm{m} \mathrm{depth}$ ) water. We included these measures of water column stratification in our correlation analysis. Follow-up linear regression analyses determined the percent variance accounted for by each related variable.

\section{RESULTS}

\section{Hydrography}

In BIS, a weak thermocline formed during the late spring and lasted until the fall (Fig. 3a), and there was a weak halocline throughout the year along with fresher surface water in winter and spring (Fig. 3b). In RIS, thermal stratification began in the spring, and the system became more stratified throughout the summer/fall (Fig. 3c). There was also very weak salinity stratification at most times throughout the year, and pools of fresh surface water in the winter, spring, and fall (Fig. 3d). Stratification in BIS, while persistent year-round, was always much weaker than spring/summer conditions in RIS. In RIS, the winter stratification essentially vanished, resulting in a much sharper seasonal cycle (Ullman \& Codiga 2010). The average measured $Z_{\mathrm{p}}$ was $19.3 \mathrm{~m}$ in BIS and $23 \mathrm{~m}$ in RIS.

\section{Chl a}

During the 22 mo sampling period, surface chl $a$ concentrations ranged from 0.27 to $8.58 \mathrm{mg} \mathrm{m}^{-3}$ in BIS and 0.17 to $9.76 \mathrm{mg} \mathrm{m}^{-3}$ in RIS. As is typical of chlorophyll concentrations, the data were lognormally distributed, so we compared the geometric means (Campbell 1995). We excluded 1 very high outlier from the analysis, which was likely due to analytical error. Overall mean surface chl a concentrations in BIS $\left(1.86 \mathrm{mg} \mathrm{m}^{-3}\right)$ and RIS $\left(1.69 \mathrm{mg} \mathrm{m}^{-3}\right)$ were not significantly different from each other. The phenology of phytoplankton biomass was also consistent between both Sounds. During the first year of data collection, surface chl a concentrations in both Sounds peaked during the winter/spring (January to March), and reached a second, larger peak during the fall (October and November; Fig. 2a,c). The bimodal peaks were also present during Year 2, though there were far less data available.

$\mathrm{Chl}$ a measured in surface water samples was significantly correlated with surface water salinity $(\mathrm{r}=$ $0.54, p=0.04)$, and was negatively correlated with both water column stratification $(\mathrm{r}=-0.51, \mathrm{p}=0.01)$ and $Z_{\mathrm{p}}(\mathrm{r}=-0.54, \mathrm{p}=0.05) . Z_{\mathrm{p}}$ explained the largest 

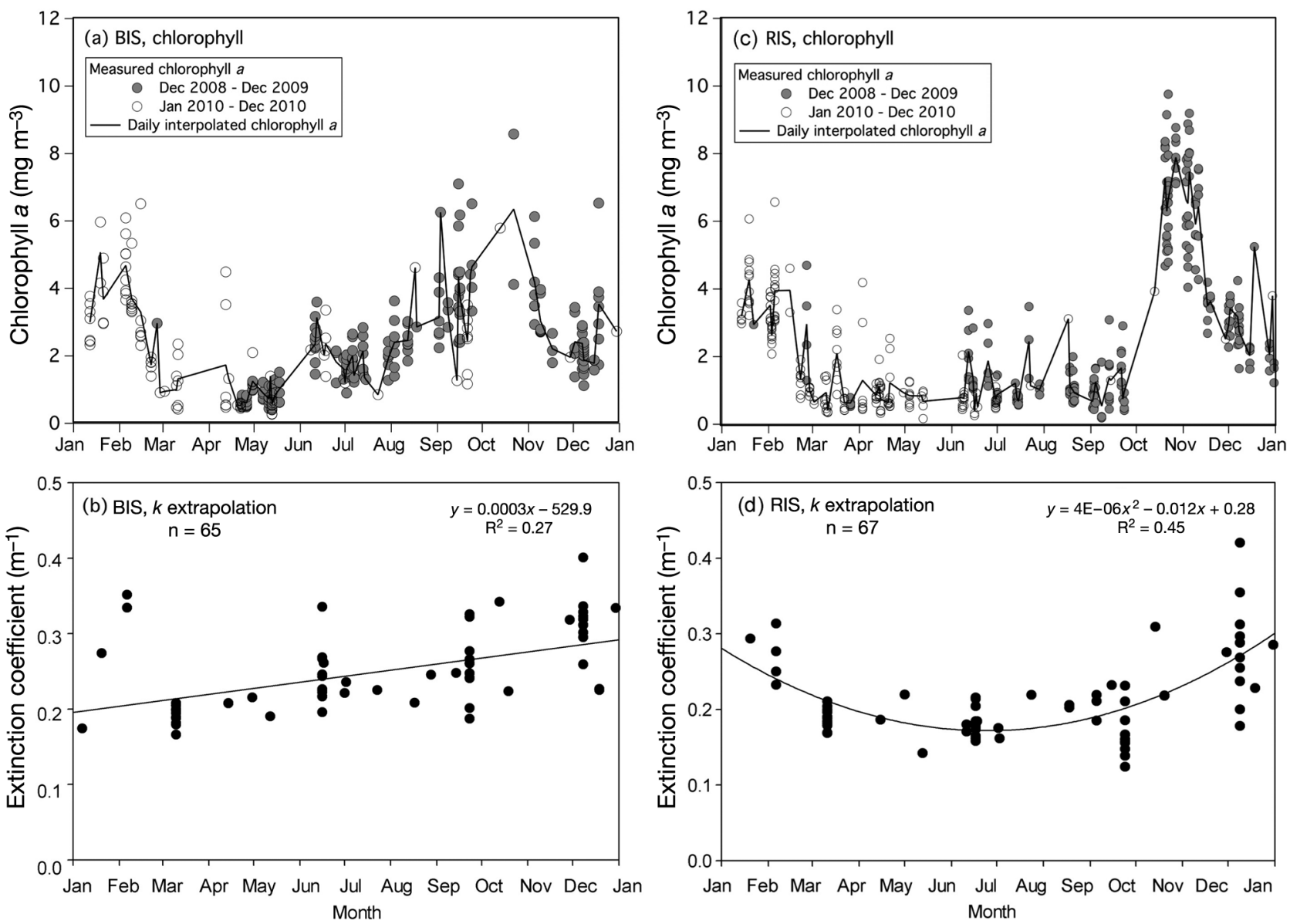

Fig. 2. Daily variable input values for the BZE models of primary production shown with in situ measurements. (a,c) Surface chl a was linearly interpolated (solid line) between daily average measurements for both Sounds. Points are the mean of triplicate samples collected at each station throughout the 22 mo sampling period. $(\mathrm{b}, \mathrm{d})$ Extinction coefficients $(k$, used to calculate the $1 \%$ light level) were extrapolated using the best fit

amount of variance in chl a data $(42 \%$; Fig. 4 a), followed by stratification (26\%; Fig. 4b) and salinity (19\%; Fig. 4c). There was no significant relationship between chlorophyll and either temperature or PAR.

After filtering the satellite chlorophyll observations to meet the criteria for inclusion (see 'Materials and methods: Validation of Sea WiFs chl a'), a sample size of $\mathrm{n}=93$ remained for the comparison between in situ measurements versus satellite data. The ship-based measurements and satellite observations derived using the Pan et al. $(2008,2010)$ regional algorithm had a better fit and explained a higher percent of the variance (slope $=0.96, R^{2}=0.41$; Fig. 5a) compared to the OC4 algorithm (slope $=0.59, \mathrm{R}^{2}=0.34$; Fig. 5b). The comparison with the regional algorithm exhibited a slope reflective of a nearly 1:1 relationship, however the satellite algorithm tended to overestimate in situ chlorophyll at low concentrations, and predict higher chlorophyll concentrations less definitively (Fig. 5a). Additionally, the regional algorithm showed bias at chlorophyll concentrations around 2 to $7 \mathrm{mg} \mathrm{m}^{-3}$; satellite values tended to overestimate in situ measurements of chlorophyll in RIS, but underestimate those in BIS (Fig. 5a). The $12 \mathrm{yr}$ time series of surface chlorophyll constructed using the regional algorithm indicated that phytoplankton biomass was higher overall in BIS (mean $=1.50 \mathrm{mg} \mathrm{m}^{-3}$ ) than in RIS (mean $=0.86 \mathrm{mg} \mathrm{m}^{-3}$ ), and that the largest difference between the 2 Sounds occurred during the summer and fall, when chlorophyll was at a minimum in RIS (Fig. 6).

\section{Primary production}

${ }^{14} \mathrm{C}$ measured primary production was significantly correlated with surface water temperature $(\mathrm{r}=0.57$, $\mathrm{p}=0.03$; Fig. $4 \mathrm{~d}$ ), but we found no relationship between production and any other measured forcing variable (salinity, stratification, PAR, or $Z_{\mathrm{p}}$ ). There 
(a)
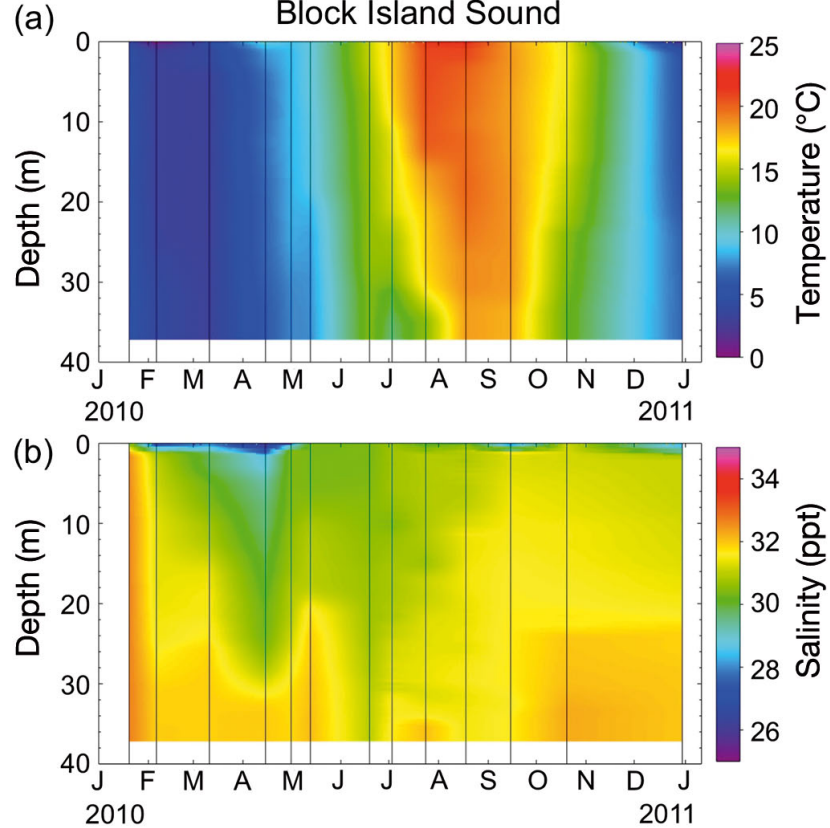

(c)
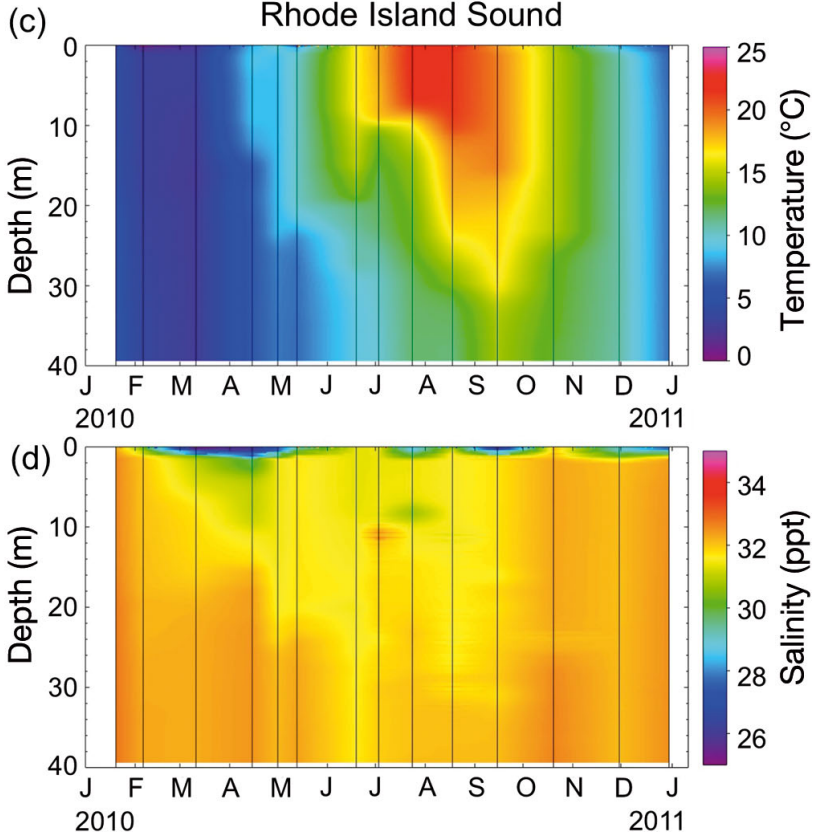

Fig. 3. Annual $(\mathrm{a}, \mathrm{c})$ temperature and $(\mathrm{b}, \mathrm{d})$ salinity regimes at the primary production samplings stations in $(\mathrm{a}, \mathrm{b})$ Block Island Sound and (c,d) Rhode Island Sound. Black lines: days on which CTD casts were taken

was a weak but significant correlation between measured primary production and chl a $(\mathrm{r}=0.38, \mathrm{p}=0.04)$ for both study areas (BIS and RIS) combined, and chlorophyll explained only $15 \%$ of the variance in primary production $(\mathrm{p}=0.04$; Fig. $7 \mathrm{a})$. When each Sound was considered individually, however, there were no significant relationships between surface chlorophyll and primary production. $P^{B}{ }_{\mathrm{d}}$ ranged from 0.66 to $28.52 \mathrm{mg} \mathrm{C} \mathrm{mg} \mathrm{chl} a^{-1} \mathrm{~d}^{-1}$ in BIS, and from 0.86 to $33.60 \mathrm{mg} \mathrm{C} \mathrm{mg} \mathrm{chl} a^{-1} \mathrm{~d}^{-1}$ in RIS. Peaks in $P^{B}{ }_{\mathrm{d}}$ occurred during the summer in both Sounds, and rates were minimal during the winter months (Fig. 7b).

The regression equations for BZE models made for both RIS and BIS were statistically significant ( $p<$ 0.0001 ; Fig. 8). Modeled annual primary production was higher in the more well-mixed BIS (318 to $329 \mathrm{~g}$ $\mathrm{C} \mathrm{m}^{-2} \mathrm{yr}^{-1}$ ) than in seasonally stratified RIS (239 to $256 \mathrm{~g} \mathrm{C} \mathrm{m}^{-2} \mathrm{yr}^{-1}$; Table 3). Modeled daily average primary production was significantly higher in BIS $\left(887.6 \pm 27.3 \mathrm{mg} \mathrm{C} \mathrm{m}^{-2} \mathrm{~d}^{-1}\right)$ than in RIS (669.5 \pm $\left.20.8 \mathrm{mg} \mathrm{C} \mathrm{m}^{-2} \mathrm{~d}^{-1} ; F_{1,1400}=40.3, \mathrm{p}<0.0001\right)$. Primary production reached its maximum in late summer in BIS (Fig. 9a, Table 3). This was followed by a second, but slightly smaller peak in mid-October, after which production levels decreased to their lowest values in the winter (Fig. 9a). In RIS, peaks in production occurred simultaneously with those in BIS, but the peak magnitudes were different between the Sounds; peaks in RIS were lower than those in BIS (Fig. 9b).
BZE models for both Sounds had negative $y$-intercepts; these deviations of the $y$-intercept from the origin occurred as an artefact of fitting the regression line to the data (Brush et al. 2002). Forcing the regression lines through the origin would correct this, but we chose not to do so to avoid altering the slope of the regression line, and because none of the $y$-intercepts were significantly different from zero. We instead assigned all negative production rates a value of zero when integrating daily rates to seasonal and annual values (Table 3 ).

\section{DISCUSSION}

\section{Hydrographic regimes}

The CTD casts made at both of our ${ }^{14} \mathrm{C}$ sampling stations throughout the year were consistent with previous studies of temperature and salinity regimes in BIS and RIS (Fig 3; e.g. Shonting \& Cook 1970, Snooks et al. 1977, Codiga \& Ullman 2010). Despite their proximity, there are substantial differences in hydrography between BIS and RIS (for a detailed literature review, see Codiga \& Ullman 2010). Throughout the year, the water column in BIS is much less stratified than the water column in RIS (Fig. 3a,c) because of stronger tidal currents and, less importantly, freshwater influence. Both Sounds have a seasonal temperature cycle that ranges from approxi- 

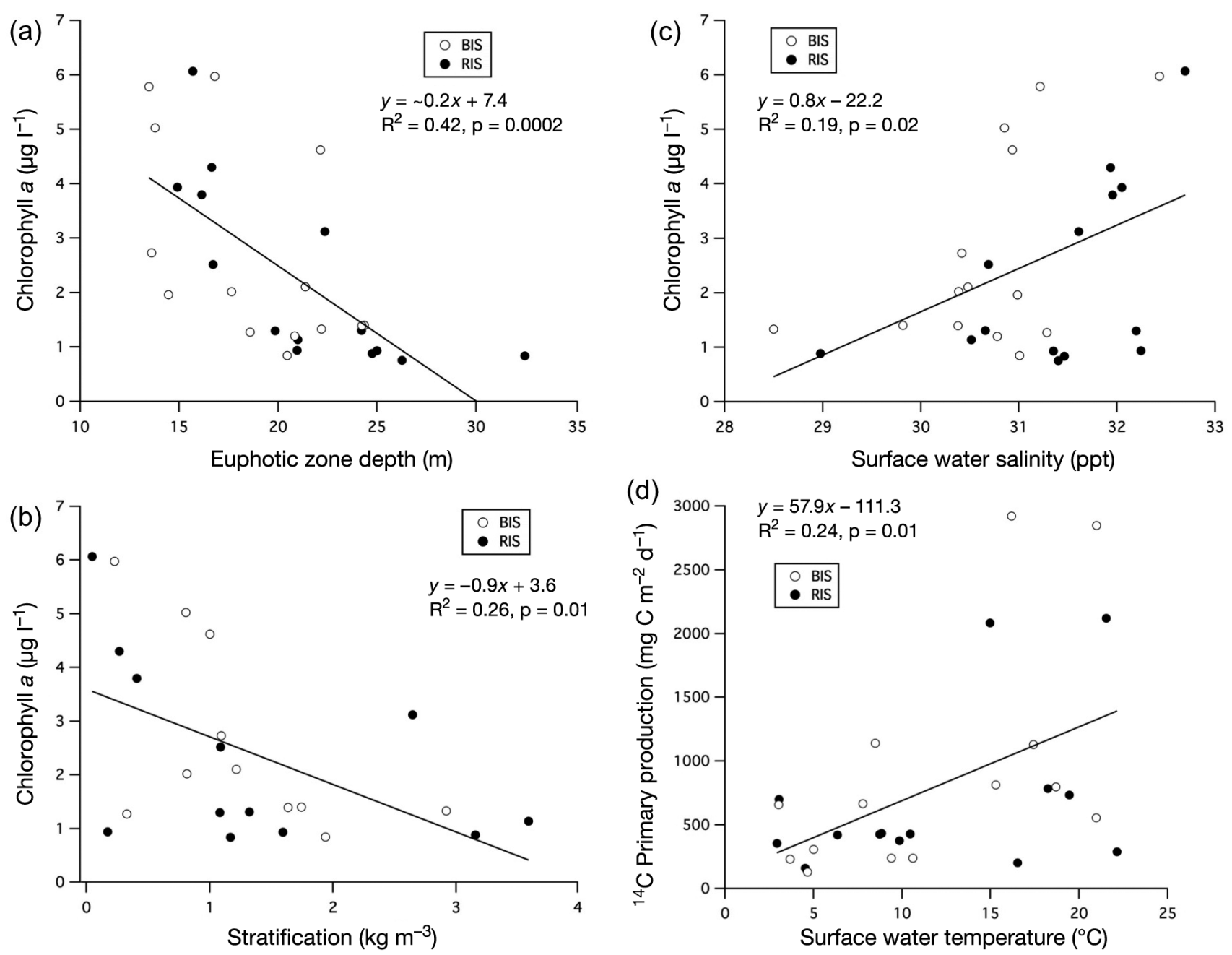

Fig. 4. Significant relationships between $(\mathrm{a}, \mathrm{b}, \mathrm{c})$ chlorophyll and $(\mathrm{d})$ primary production and measured forcing variables, including (a) depth of the euphotic zone, (b) water column stratification, (c) surface water salinity, and (d) surface water temperature. Regression equations represent data from both stations combined. BIS: Block Island Sound; RIS: Rhode Island Sound

mately 3 to $21^{\circ} \mathrm{C}$, but surface waters during spring/ summer tend to be cooler in BIS than in RIS (Fig. 3a,c) because of stronger vertical mixing due to stronger tidal currents. We found that seasonal formation of a mid-depth thermocline began in April and broke down around September in RIS (Fig. 3c), which is consistent with previous studies of northeastern BIS (Snooks et al. 1977) - farther away from the influence of the Long Island Sound (LIS) outflow-and western-central and eastern-central RIS. Temperatures became nearly homogeneous throughout the water column in fall and winter (Fig. 3c) due to wind mixing (Shonting \& Cook 1970). During the summer, the stratification peak that occurred in RIS did not occur in BIS (Fig. 3a) because of the stronger tidal currents mixing, which resulted in BIS being the more wellmixed system. Both BIS and RIS exchange water with adjacent inshore ecosystems, but the estimated long- term mean volume transport exchange between BIS and LIS is an order of magnitude greater than with any other body of water $\left(23 \pm 5 \times 10^{3} \mathrm{~m}^{3} \mathrm{~s}^{-1}\right.$; Codiga \& Aurin 2007, Codiga \& Ullman 2010). This interaction has probably the most important influence on the BIS-RIS region (Codiga \& Ullman 2010), and contributes to differences between the Sounds because of the closer proximity of BIS to LIS.

There was a weak annual cycle of salinity in both Sounds (Fig. 3b,d); variations were due to the influence of interactions with surrounding estuaries (Snooks et al. 1977, Codiga \& Ullman 2010). Freshwater influence occurred in BIS to a greater extent than in RIS due to its proximity to LIS (Fig. 1), where a strong estuarine exchange flow brings Connecticut Riverfreshened water out through BIS (Ichiye 1967, Williams 1969, Hardy 1972, Hollman 1974, Codiga \& Aurin 2007, Codiga \& Ullman 2010). This exchange 

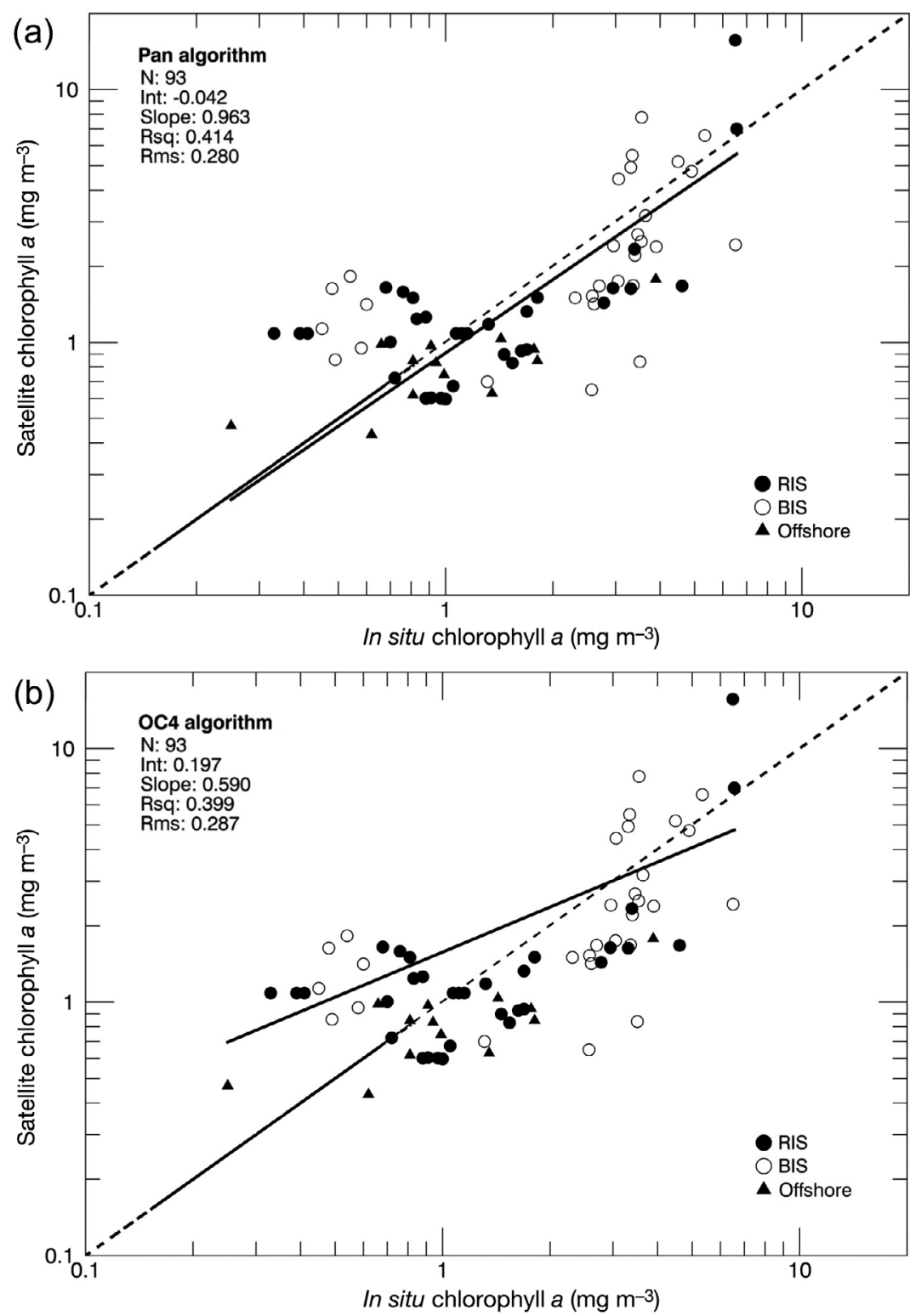

Fig. 5. Reduced major axis regressions of measured surface chl a versus SeaWiFs satellite values calculated using (a) the regional algorithm developed by Pan et al. $(2008,2010)$ for the mid-Atlantic Bight, and (b) the traditional ocean OC4 algorithm for Rhode Island Sound (RIS), Block Island Sound (BIS), and samples collected outside of our study area (Offshore)

has much less of an influence on RIS because the fresher water mainly flows south out of BIS through the gap between Montauk Point, NY and Block Island (Fig 1a; Codiga 2005, Ullman \& Codiga 2010).

\section{Comparison of BIS and RIS}

Despite the long history of commercial fishing success on the northwest Atlantic shelf as a whole (Sher- man et al. 1996), very few measurements of phytoplankton biomass have been made in the BIS-RIS area, and until recently, few studies of the 2 Sounds had been published at all. In the 1940s, Riley (1952) made the first measurements of phytoplankton biomass in northwestern BIS. Studies conducted by Staker \& Bruno $(1978 a, b)$ and those within the Marine Monitoring, Assessment, and Prediction Program (MARMAP; Pearce 1981, O'Reilly et al. 1987, Sherman et al. 1996, O'Reilly \& Zetlin 1998) also addressed phytoplankton dynamics nearby, but no sampling stations were located within the heart of BIS and RIS. Thus, our measurements fill a long-standing gap in knowledge for these inner shelf regions.

The most remarkable feature of the annual chlorophyll cycle was a strong fall phytoplankton bloom that occurred in both Sounds (Fig. 2a,c), concurrent with high rates of primary production (Fig. 9). The weak but significant relationship between phytoplankton biomass (chlorophyll) and production was driven by this occurrence in both Sounds. Statistically, the most important forcing variables for phytoplankton abundance that we measured were water column stratification, depth of the euphotic zone, and salinity in surface waters. More specifically, we measured the highest phytoplankton biomass in surface waters of a less stratified water column with oceanic (relatively higher) surface salinity and a shallow euphotic zone. During the fall bloom, these conditions were present in both Sounds; in RIS this occurred at the breakdown of the seasonal thermocline, and the water column in BIS was relatively well mixed (Fig. 3a,b). In shallow estuarine and inner continental shelf ecosystems, the relationship between phytoplankton phenology and the physical variability of the water column is often complex (Koseff et al. 1993). It has been shown that very little water column stability is necessary to elicit a bloom, especially in nutrient-rich coastal waters (Townsend et al. 1992). We found this to be true during both the fall and the winter/spring phytoplankton 
(a)

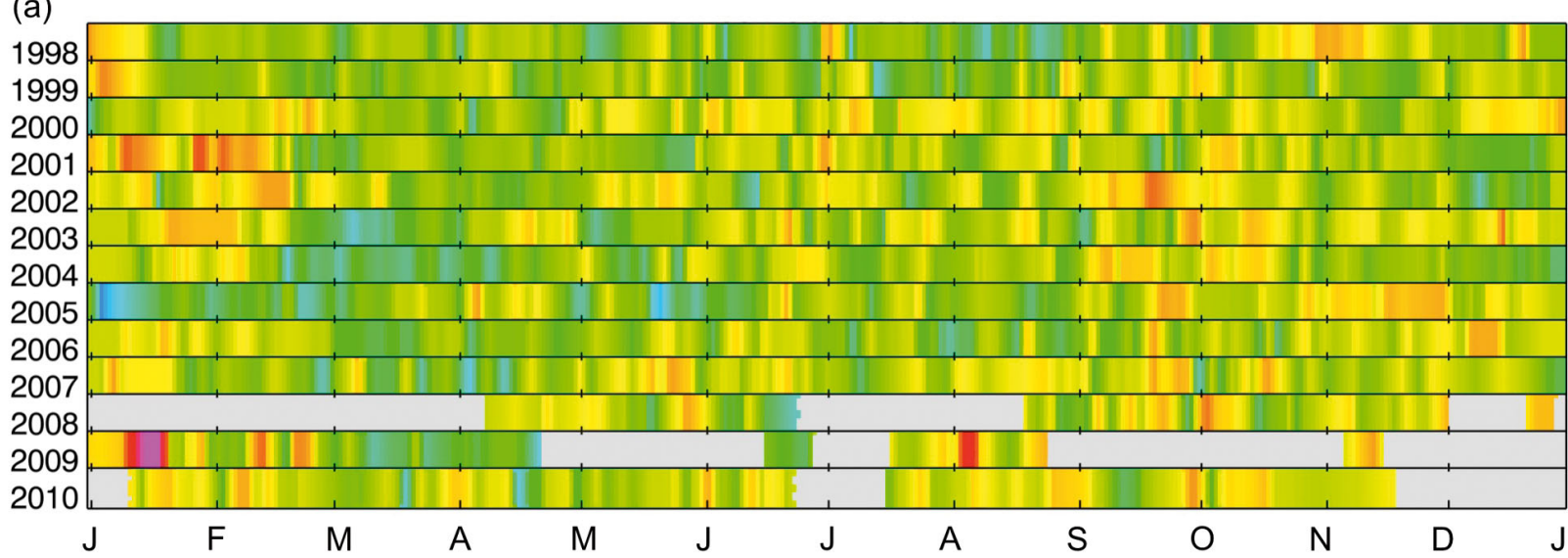

(b)

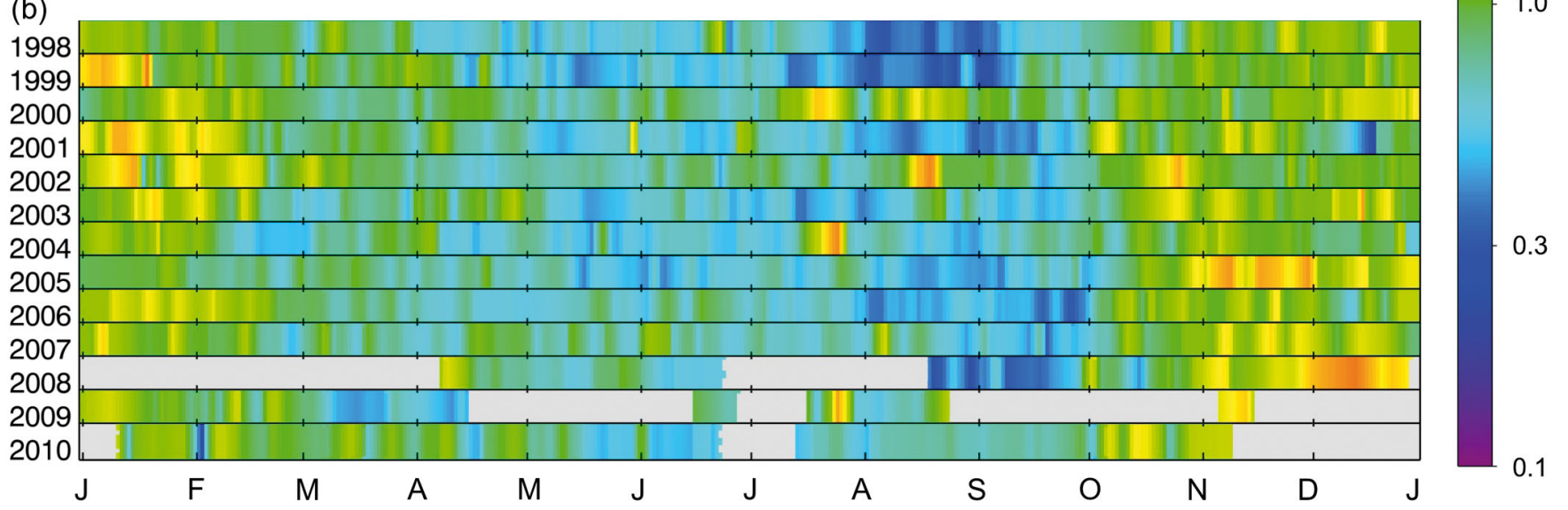

Chlorophyll a $\left(\mathrm{mg} \mathrm{m}^{-3}\right)$

10.0

3.0

Fig. 6. Daily interpolated SeaWiFs chl a (Pan et al. 2008, 2010) from 1998 to 2010 in (a) Block Island Sound and (b) Rhode Island Sound. Note the color bar is a $\log _{10}$ scale. Grey areas indicate periods of time during which no satellite data were available

blooms in both Sounds when the water column stratification was minimal. Surface salinity is probably negatively correlated with stratification (i.e. lower surface salinity when stratification is stronger) because the stratification is due to fresher water over water of higher salinity. Unless the species involved are highly sensitive to salinity, the mechanism linking phytoplankton abundance to lower stratification (and in turn higher surface salinity) is the effect of stratification.

In both Sounds, there was a late summer peak in primary production with no concurrent phytoplankton bloom. We measured high phytoplankton-specific production $\left(P_{\text {di }}^{B}\right.$ i.e. turnover $)$ during the summer in both Sounds (Fig. 7b), which would explain why biomass levels remained so low during this peak in production. We cannot say with certainty what caused this high phytoplankton-specific production, which, according to the literature, is not unusual. In nearby Narragansett Bay, there is a shift in the phytoplankton population towards smaller species (nanoplankton) with high turnover rates during the sum- mer (Durbin et al. 1975), and this kind of shift might also be occurring in the BIS-RIS area. Zooplankton grazing is also a typical explanation of high production and low chlorophyll during summer in the temperate ocean. Early work by Riley (1952) suggested that zooplankton quantity was likely not an important factor in governing phytoplankton dynamics in the BIS area; however, an analysis of zooplankton dynamics is outside of the scope of this study.

Though the standing crop of phytoplankton was not significantly different between the Sounds, primary production per unit area was significantly higher in BIS than in RIS. The higher rates of daily and annual primary production measured in BIS were due in large part to differences in production between the Sounds during the summer, when production peaked in both Sounds but was nearly $50 \%$ higher in BIS than in RIS (Table 3). These differences occurred concurrently with the most drastic differences in water column stratification between BIS (very weak/no stratification) and RIS (strong stratifi- 

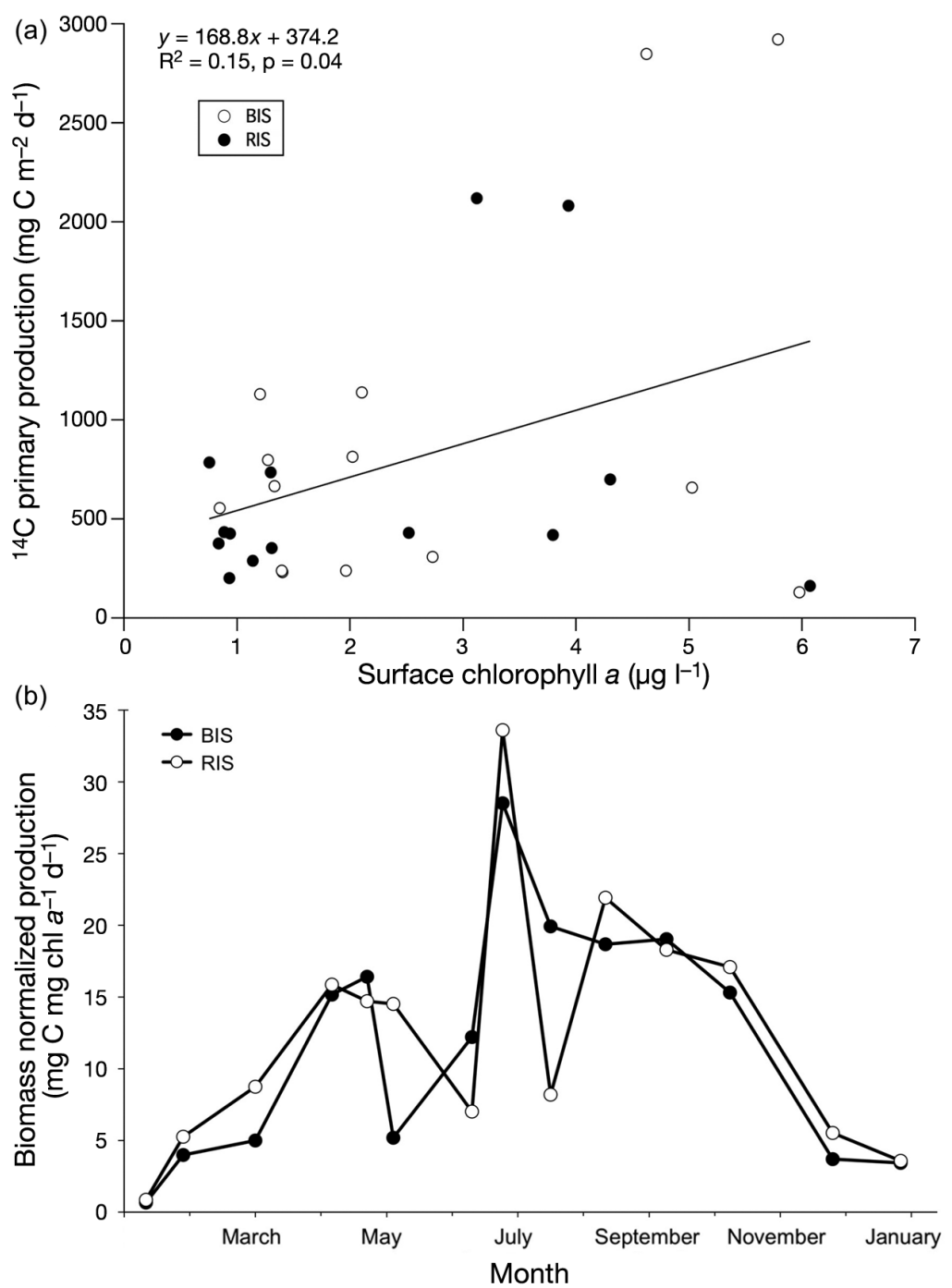

mer (e.g. Kremer \& Nixon 1978, Oviatt et al. 1995, Smayda \& Borkman 2008). We hypothesize that deep, DIN-rich water entering the Sounds from the outer shelf along with DIN regenerated from the sediments is more rapidly mixed up into the surface waters in BIS because it is less inhibited by density stratification. We suspect that the presence of a strong pycnocline in RIS facilitated rapid use and depletion of available nutrients in surface waters of the stratified area, making summer productivity in RIS sustained mostly on regenerated nutrients that quickly overturn to maintain the productivity levels (Malone et al. 1988, Cushing 1989). In other coastal marine ecosystems, water column stratification causes nutrient limitation in the surface waters over time as phytoplankton deplete the nutrient supply above the pycnocline (Taft et al. 1980). Sustenance of summer production on regenerated nutrients is typical in estuarine ecosystems (e.g. Chesapeake Bay: Boynton et al. 1982, Malone et al. 1988), and within the thermocline of temperate waters (Cushing 1989).

\section{Comparison with other coastal marine ecosystems}

Fig. 7. (a) Surface chlorophyll versus measured $\left({ }^{14} \mathrm{C}\right)$ primary production, and (b) measured primary production normalized to biomass $\left(P_{\mathrm{d}}^{B}\right.$, in $\mathrm{mg} \mathrm{C}$ mg chl $a^{-1} \mathrm{~d}^{-1}$ ) throughout 2010. BIS: Block Island Sound; RIS: Rhode Island Sound

cation). In other words, phytoplankton were highly productive during the summertime stratification in RIS, but never achieved the same magnitude of productivity as in the adjacent, more well-mixed BIS. At this time we cannot definitely identify the underlying mechanism for these differences in production, but we provide a hypothesis. Though we do not have direct measurements of nutrient availability in the water column, we suspect that the supply of dissolved inorganic nitrogen (DIN) in surface waters is strongly regulated by water column stratification. There is strong evidence that the supply of DIN is one of the most important factors limiting phytoplankton production and biomass in southern New England coastal waters, especially during the sum- tems, Cebrián \& Valiela (1999) found that $65 \%$ of the systems they assessed exhibited the same pattern, although the winter/spring peak in BIS and RIS occurred about a month earlier than the majority of systems surveyed. This pattern has been observed in most regions surrounding BIS and RIS on the northeast US continental shelf (Gulf of Maine, Georges Bank, Mid-Atlantic Bight: O'Reilly \& Zetlin 1998). However, in these areas the highest concentrations occurred during the winter/spring bloom instead of the fall bloom (O'Reilly \& Zetlin 1998). Peaks in both Sounds had higher concentrations than are typical for most open coastal systems (Cebrián \& Valiela 1999). Rates of primary production in both Sounds were similar to those of nearby inner continental shelf systems, including Massachusetts Bay 

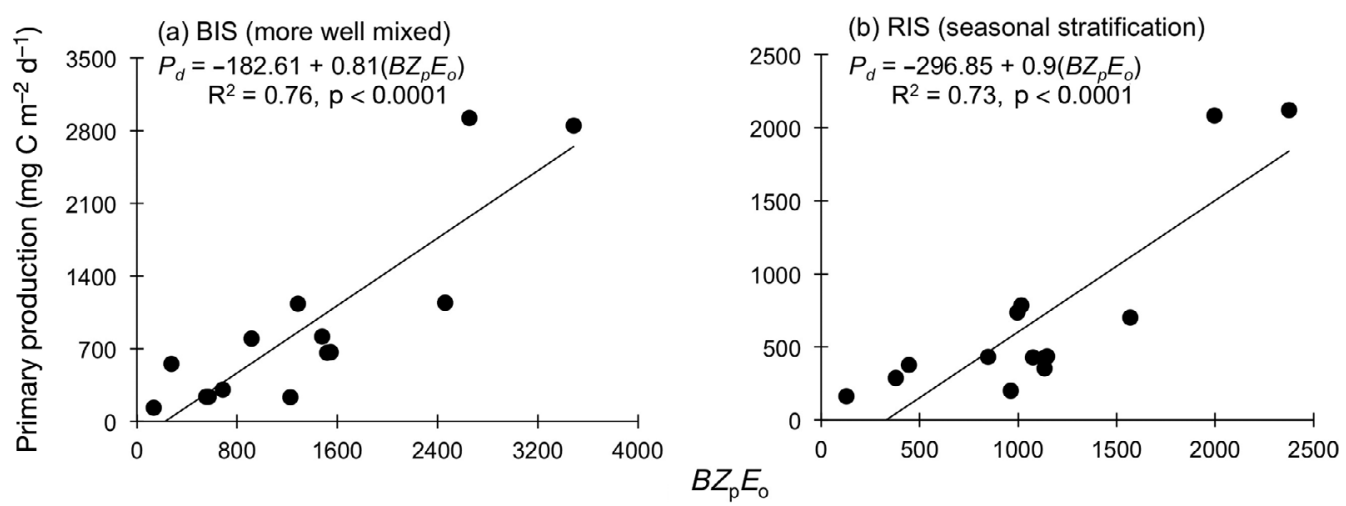

Fig. 8. Empirical regressions of measured daily primary production versus the composite parameter $B Z_{\mathrm{p}} E_{\mathrm{o}}$ (where $B$ is phytoplankton biomass, $Z_{\mathrm{p}}$ is the depth of the photic zone, and $E_{\mathrm{o}}$ is ambient daily PAR) for (a) Block Island Sound and (b) Rhode Island Sound

Table 3. Seasonal and annual primary production model outputs for Block Island Sound (BIS) and Rhode Island Sound (RIS). Values given are for both the Webb/Platt (W/P) and BZE models. Winter: Dec to Feb; Spring: Mar to May; Summer: Jun to Aug; Fall: Sep to Nov. Primary production is given in $\mathrm{g} \mathrm{C} \mathrm{m}^{-2}$ season ${ }^{-1}$ (for winter, spring, summer and fall) and in $\mathrm{g} \mathrm{C} \mathrm{m}^{-2} \mathrm{yr}^{-1}$ (for annual rates)

\begin{tabular}{|lcccc|}
\hline & \multicolumn{2}{c|}{$\begin{array}{c}\text { BIS production } \\
\left(\mathrm{g} \mathrm{C} \mathrm{m}^{-2}\right)\end{array}$} & \multicolumn{2}{c|}{$\begin{array}{c}\text { RIS production } \\
\left(\mathrm{g} \mathrm{C} \mathrm{m}^{-2}\right)\end{array}$} \\
& W/P & BZE & W/P & BZE \\
\hline Winter & 43 & 49 & 47 & 45 \\
Spring & 43 & 48 & 34 & 39 \\
Summer & 134 & 130 & 86 & 73 \\
Fall & 110 & 92 & 89 & 82 \\
Annual & 329 & 318 & 256 & 239 \\
\hline
\end{tabular}

(Kelly \& Doering 1997, Keller et al. 2001, Hyde et al. 2008) and Georges Bank (Riley 1941 as cited in Kuring et al. 1990, O'Reilly et al. 1987, Sherman et al. 1996).

\section{Surface chlorophyll concentrations on annual and decadal time scales}

Satellites have the ability to integrate data across both space and time in a way that ship-based sample collection does not allow. Given the high variability in phytoplankton dynamics, continuous monitoring of biomass (as chl a) via ocean color remote sensing is a powerful tool for synthesizing trends of phytoplankton phenology. Retrieving accurate chlorophyll measurements from remotely sensed ocean color data in coastal areas is more difficult compared to the open ocean due to interference of the optical signal received by the satellite caused by dissolved and sus- pended materials in the water (Morel \& Prieur 1977, IOCCG 2000) and higher concentrations of absorbing aerosols that lead to errors in chl a calculations (Stumpf et al. 2003). However, the development of regional algorithms calibrated using in situ measurements from specific areas has greatly improved the accuracy of remotely sensed chl a values in coastal regions, and reduced the error associated with satellite observations and post-processing of data in coastal areas (e.g. Hyde et al. 2007, Pan et al. 2008).

Despite the in situ surface chl a measurements indicating that phytoplankton biomass was not significantly different between BIS and RIS, satellite observations over a longer time period tell a different story (Fig. 6). Chlorophyll concentrations appear to be higher throughout the entire satellite time series in BIS than in RIS, almost without exception, and the mean annual chlorophyll concentration in BIS is nearly double that of RIS. We cannot rule out the possibility that the data density of our in situ measurements was insufficient to reveal biomass differences, or that the 2 yr during which we sampled were anomalous. For example, during the late fall-early winter of 2009, there was an intrusion of deep water from the continental slope into RIS, causing anomalies in nearbottom salinity, temperature, density, and possibly nutrients that likely mixed with inner shelf water (Ullman \& Codiga 2010, Ullman et al. 2014). We also point out that although the regional algorithm has greatly improved the accuracy of satellite ocean color data relative to the uncorrected (OC4) algorithm, there are still issues with predictability of low $\left(<1 \mathrm{mg} \mathrm{m}^{-3}\right.$ ) concentrations as well as an apparent bias in chlorophyll predictability between stations in the range of $\sim 2$ to $7 \mathrm{mg} \mathrm{m}^{-3}$. However, the satellite data appear to capture longer-term regional patterns that our ship-based measurements fail to capture. 


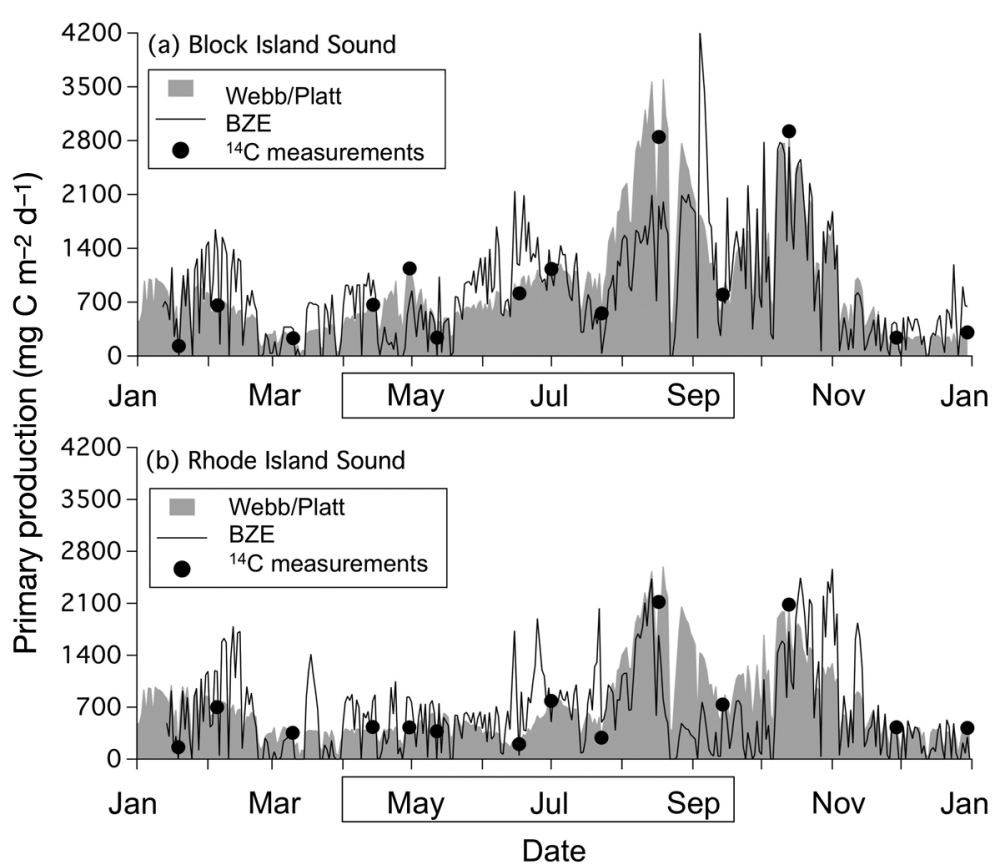

Fig. 9. Comparison of daily primary production $\left({ }^{14} \mathrm{C}\right)$ measurements, Webb/Platt model outputs, and BZE model outputs in (a) Block Island Sound and (b) Rhode Island Sound. The box around April through September indicates the period of time during which water column stratification was most different between BIS (very weak/no stratification) and RIS (strong stratification)

\section{CONCLUSIONS}

Despite their proximity to each other, there are differences in the hydrography between BIS and RIS. RIS exhibits strong summer stratification and becomes unstratified in winter, while BIS is the more well-mixed system due to its proximity to LIS estuarine circulation and stronger tidal currents. Using empirical models of primary production and ocean color satellite data enabled us to make a more thorough comparison between the 2 areas than would have been possible with direct measurements alone. There were similarities in phytoplankton dynamics between the Sounds, including bimodal peaks of production and biomass, and a strong fall bloom that was driven at least in part by physical mixing of the water column. We also measured a second peak in primary production in both Sounds during the summer that was unaccompanied by an increase in biomass due to high phytoplankton turnover. The overall measured standing stock of phytoplankton was not significantly different between the Sounds, but primary production and satellite surface chlorophyll were higher in BIS than in RIS. The difference in primary production predominantly occurred during summer, when production peaked in both Sounds but was nearly $50 \%$ higher in BIS than in RIS. We cannot identify the underlying mechanism for this difference, though we hypothesize that differences in water column stratification fostered surface nutrient limitation that limited production in RIS.

In general, our findings appear to support Riley's (1952) postulation that physical processes strongly affect both the community size and structure of phytoplankton in the BIS area, though we cannot definitely say that physics are the most important forcing factor without a more thorough examination of other 'bottom-up' (e.g. nutrient limitation) and 'top-down' (e.g. grazing pressure) controls. As more work is conducted in these areas, the relative importance of such factors will become evident.

An increasing number of in-depth studies in various disciplines have been conducted in BIS and RIS over the past few years by a number of investigators (e.g. Kincaid et al. 2008, Ullman \& Codiga 2010, Heiss et al. 2012, Fields et al. 2014), and their results have sparked additional interest and further exploration. Re-evaluating these results as additional work is conducted will allow us to put our data into context with other chemical, biological, physical, and geological processes that are presently occurring in these 2 systems. We are only just beginning to understand the ecosystem dynamics of these areas and establish a baseline of knowledge that will assist with management issues such as fisheries and the potential for wind farm development, and enable us to understand and predict ecosystem response to global environmental change.

Acknowledgements. S.W.N., C.O., D.U., and D.C. were funded to complete this study by the CRMC's OSAMP. L.F. was supported by funding from the RI CRMC, the Rhode Island Sea Grant College Program, the National Science Foundation (OCE 0926875), and the URI-GSO Alumni Association Fellowship Program. Work done by L.F. was also supported in part by the QLF Sounds Conservancy Grant Program. This material is based upon work supported in part by the National Science Foundation EPSCoR Cooperative Agreement EPS-1004057 and the State of Rhode Island. Many thanks to S. Granger for his help during fieldwork and chlorophyll sample processing, and to L. Windecker for assistance in establishing laboratory protocols. We thank R. Sykes and his crew of the F/V 'Virginia Marise', and M. Marchetti, who collected many surface chlorophyll samples and assisted in field support. Thanks also to P. Paton, 
S. McWilliams, K. Winiarski, and J. King who assisted with chlorophyll sample collection. Others who assisted with laboratory and fieldwork are: D. Maggio, E. Fisher, and L. Portis. Thanks to B. Oakley for help with field support, and to A. Drzewianowski for maintaining the fluorometer. We also thank R.W. Fulweiler, A. Gold, M. E. Q. Pilson, P. August, and A. Giblin for comments and discussion that improved the manuscript. This paper is Contribution No. 3472 of the Virginia Institute of Marine Science, College of William \& Mary.

\section{LITERATURE CITED}

Arar EJ, Collins GB (1997) Method 445.0: in vitro determination of chlorophyll $a$ and pheophytin $a$ in marine and freshwater algae by fluorescence. US Environmental Protection Agency, Cincinnati, $\mathrm{OH}$

Bailey SW, Werdell PJ (2006) A multi-sensor approach for the on-orbit validation of ocean color satellite data products. Remote Sens Environ 102:12-23

Banse K (1994) Grazing and zooplankton production as key controls of phytoplankton production in the open ocean. Oceanography 7:13-20

Boynton W, Kemp WM, Keefe CW (1982) A comparative analysis of nutrients and other factors influencing estuarine phytoplankton production. In: Kennedy VS (ed) Estuarine comparisons. Academic Press, New York, NY, p 69-90

Bricaud A, Bosc E, Antione D (2002) Algal biomass and sea surface temperature in the Mediterranean Basin: intercomparison of data from various satellite sensors, and implications for primary production estimates. Remote Sens Environ 81:163-178

Brush MJ, Brawley JW, Nixon SW, Kremer JN (2002) Modeling phytoplankton production: problems with the Eppley curve and an empirical alternative. Mar Ecol Prog Ser 238:31-45

Calabretta CJ (2009) Benthic macrofauna in Narragansett Bay, Rhode Island: an examination of factors causing variability in community structure. PhD thesis, University of Rhode Island, Narragansett, RI

> Campbell JW (1995) The lognormal distribution as a model for bio-optical variability in the sea. J Geophys Res 100: 13237-13254

> Cebrián J, Valiela I (1999) Seasonal patterns in phytoplankton biomass in coastal ecosystems. J Plankton Res 21:429-444

> Christensen JP, Murray JW, Devol AH, Godispoti LA (1987) Denitrification in continental shelf sediments has major impact on the oceanic nitrogen budget. Global Biogeochem Cycles 1:97-116

Codiga DL (2005) Interplay of wind forcing and buoyant discharge off Montauk Point: seasonal changes in velocity structure and a coastal front. J Phys Oceanogr 35: 1068-1085

Codiga DL, Aurin DA (2007) Residual circulation in eastern Long Island Sound: observed transverse-vertical structure and exchange transport. Cont Shelf Res 27:103-116

Codiga DL, Ullman DS (2010) Characterizing the physical oceanography of coastal waters off Rhode Island, Part 1: Literature review, available observations, and a representative model simulation. Rhode Island Ocean Special Area Management Plan Tech Rep 2, Rhode Island Coastal Resources Management Council, Wakefield, RI www.crmc.ri.gov/samp_ocean/finalapproved/TechRep0
2-PhysOcPart1-CodigaUllman2010.pdf

Cole BE, Cloern JE (1987) An empirical model for estimating phytoplankton productivity in estuaries. Mar Ecol Prog Ser 36:299-305

- Costanza R, D'Arge R, De Groot R, Farber S and others (1997) The value of the world's ecosystem services and natural capital. Nature 387:253-260

> Cushing DH (1989) A difference in structure between ecosystems in strongly stratified waters and in those that are only weakly stratified. J Plankton Res 11:1-13

Doyon P, Klein B, Ingram RG, Legendre L, Tremblay JÉ, Therriault JC (2000) Influence of wind mixing and upperlayer stratification on phytoplankton biomass in the Gulf of St. Lawrence. Deep-Sea Res II 47:415-433

> Durbin EG, Krawiec RW, Smayda TJ (1975) Seasonal studies of the relative importance of different fractions of phytoplankton in Narragansett Bay (USA). Mar Biol 32:271-287

- Fields L, Nixon SW, Oviatt C, Fulweiler RW (2014) Benthic metabolism and nutrient regeneration in hydrographically different regions on the inner continental shelf of southern New England. Estuar Coast Shelf Sci 148:14-26

- Graff JR, Rynearson TA (2011) Extraction method influences the recovery of phytoplankton pigments from natural assemblages. Limnol Oceanogr Methods 9:129-139

Hall SJ, Rogers SI, Thrush SF (2008) Continental-shelf benthic ecosystems: prospects for an improved environmental future. In: Polunin N (ed) Aquatic ecosystems: trends and global perspectives. Cambridge University Press, Cambridge, MA, p 295-308

Hardy CD (1972) Hydrographic data report: Long Island Sound, 1970, Part II. Marine Sciences Research Center, State University of New York, Stony Brook, NY

$>$ Heiss EM, Fields L, Fulweiler RW (2012) Directly measured net denitrification rates in offshore New England sediments. Cont Shelf Res 45:78-86

Holliday NP, Waniek JJ, Davidson R, Wilson D and others (2006) Large-scale physical controls on phytoplankton growth in the Irminger Sea Part I: Hydrographic zones, mixing and stratification. J Mar Syst 59:201-218

Hollman R (1974) An interdisciplinary study of the estuarine and coastal oceanography of Block Island Sound and adjacent New York coastal waters: ground truth, final report. Tech Rep No. 27, New York Ocean Science Laboratory, Montauk, NY

> Hyde KJW, O'Reilly JE, Oviatt CA (2007) Validation of SeaWiFS chlorophyll a in Massachusetts Bay. Cont Shelf Res 27:1677-1691

> Hyde KJW, O'Reilly JE, Oviatt CA (2008) Evaluation and application of satellite primary production models in Massachusetts Bay. Cont Shelf Res 28:1340-1351

Ichiye T (1967) Tidal variation of hydrography of Block Island Sound observed in August 1965. Lamont Geological Observatory, Palisades, NY

IOCCG (International Ocean-Colour Coordinating Group) (2000) Remote sensing of ocean colour in coastal, and other optically-complex waters. In: Sathyendranath S (ed) Reports of the International Ocean-Colour Coordinating Group, No 3. IOCCG, Dartmouth

Keller AA, Taylor C, Oviatt CA, Dorrington T, Holcombe G, Reed L (2001) Phytoplankton production patterns in Massachusetts Bay and the absence of the 1998 winterspring bloom. Mar Biol 138:1051-1062

Kelly JR, Doering PH (1997) Monitoring and modeling primary production in coastal waters: studies in Massachusetts Bay 1992-1994. Mar Ecol Prog Ser 148:155-168 
Kincaid C, Bergondo DL, Rosenberger K (2008) The dynamics of water exchange between Narragansett Bay and Rhode Island Sound. In: Desbonnet A, Costa-Pierce BA (eds) Science for ecosystem-based management: Narragansett Bay in the $21^{\text {st }}$ century. Springer, New York, NY, p 301-324

Knauer GA (1993) Productivity and new production of the oceanic system. In: Wollast R, Mackenzie FT, Chou L (eds) Interactions of C, N, P and S biogeochemical cycles and global change. NATO Advanced Science Institute Series Vol 4, Springer-Verlag, New York, NY, p 211-231

Koseff JR, Holen JK, Monismith SG, Cloern JE (1993) Coupled effects of vertical mixing and benthic grazing on phytoplankton populations in shallow, turbid estuaries. J Mar Res 51:843-868

Kremer JN, Nixon SW (1978) A coastal marine ecosystem: simulation and analysis. Springer-Verlag, New York, NY

$>$ Kuring N, Lewis MR, Platt T, O'Reilly JE (1990) Satellitederived estimates of primary production on the northwest Atlantic continental shelf. Cont Shelf Res 10:461-484

> Lawrenz E, Smith EM, Richardson TL (2013) Spectral irradiance, phytoplankton community composition and primary productivity in a salt marsh estuary, North Inlet, South Carolina, USA. Estuaries Coasts 36:347-364

- Lee DT, Schachter BJ (1980) Two algorithms for constructing a Delaunay triangulation. Int J Comput Inf Sci 9: 219-242

> Lewis MR, Smith JR (1983) A small volume, short-incubationtime method for measurement of photosynthesis as a function of incident irradiance. Mar Ecol Prog Ser 13: 99-102

Longhurst A (1995) Seasonal cycles of pelagic production and consumption. Prog Oceanogr 36:77-167

Malone TC, Kemp WM, Ducklow HW, Boynton WR, Tuttle $\mathrm{JH}$, Jonas RB (1986) Lateral variation in the production and fate of phytoplankton in a partially stratified estuary. Mar Ecol Prog Ser 32:149-160

- Malone TC, Crocker LH, Pike SE, Wendler BW (1988) Influences of river flow on the dynamics of phytoplankton production in a partially stratified estuary. Mar Ecol Prog Ser 48:235-249

Mantoura RF, Li B, Gieskes W, Maske H, Bidigare R (1996) Protocols for the joint global ocean flux study (JGOFS) core measurements. IOC Manuals and Guides No. 29, UNESCO, Paris

- Morel A, Prieur L (1977) Analysis of variations in ocean color. Limnol Oceanogr 22:709-722

> Muller-Karger FE, Varela R, Thunell R, Luerssen R, Hu C, Walsh JJ (2005) The importance of continental margins in the global carbon cycle. Geophys Res Lett 32:L01602, doi:10.1029/2004GL021346

Nixon SW (1981) Remineralization and nutrient cycling in coastal marine ecosystems. In: Neilson BJ, Cronin LE (eds) Estuaries and nutrients. Humana Press, Clifton, NJ, p 111-138

- Nixon SW (1988) Physical energy inputs and the comparative ecology of lake and marine ecosystems. Limnol Oceanogr 33:1005-1025

Nixon SW, Buckley BA (2002) 'A strikingly rich zone': nutrient enrichment and secondary production in coastal marine ecosystems. Estuaries 25:782-796

O'Reilly JE, Zetlin C (1998) Seasonal, horizontal, and vertical distributions of phytoplankton chlorophyll $a$ in the Northeast US continental shelf ecosystem. NOAA Tech Rep NMFS 139, US Dept Commerce, Seattle, WA
O'Reilly J, Evans-Zetlin C, Busch DA (1987) Primary production. In: Backus RH (ed) Georges Bank. MIT Press, Cambridge, MA, p 220-233

> Oviatt C, Doering P, Nowicki BL, Reed L, Cole J, Frithsen J (1995) An ecosystem level experiment on nutrient limitation in temperate coastal marine environments. Mar Ecol Prog Ser 116:171-179

> Oviatt CA, Hyde KJW, Keller A, Turner J (2007) Production patterns in Massachusetts Bay with outfall relocation. Estuaries Coasts 30:35-46

Pan X, Mannino A, Russ ME, Hooker SB (2008) Remote sensing of the absorption coefficients and chlorophyll $a$ concentration in the United States southern Middle Atlantic Bight from SeaWiFS and MODIS-Aqua. J Geophys Res 113:C11022, doi:10.1029/2008JC004852

Pan X, Mannino A, Russ M, Hooker SB, Harding LW Jr (2010) Remote sensing of phytoplankton pigment distribution in the United States northeast coast. Remote Sens Environ 114:2403-2416

Pearce JB (1981) Monitoring the health of the northeast continental shelf. In: Oceans 81: the ocean - an international workplace. IEEE, New York, NY, p 744-751

Platt T, Gallegos CL, Harrison WG (1980) Photoinhibition of photosynthesis in natural assemblages of marine phytoplankton. J Mar Res 38:687-701

Riley GA (1941) Plankton studies IV. George's Bank. Bull Bingham Oceanogr Collect 7:1-73

Riley GA (1952) Phytoplankton of Block Island Sound 1949. Bull Bingham Oceanogr Collect 13:40-64

Seitzinger SP, Styles RV, Boyer EW, Alexander RB and others (2002) Nitrogen retention in rivers: model development and application to watersheds in the northeastern USA. Biogeochemistry 57-58:199-237

Sherman K, Grosslein M, Mountain D, Busch D, O'Reilly J, Theroux R (1996) The northeast shelf ecosystem: an initial perspective. In: Sherman K, Jaworski NA, Smayda TJ (eds) The northeast shelf ecosystem: assessment, sustainability, and management. Blackwell Science, Cambridge, MA, p 103-126

Shonting DH, Cook GS (1970) On the seasonal distribution of temperature and salinity in Rhode Island Sound. Limnol Oceanogr 15:100-112

Smayda TJ, Borkman D (2008) Nutrient and plankton dynamics in Narragansett Bay. In: Desbonnet A, CostaPierce BA (eds) Science for ecosystem-based management: Narragansett Bay in the $21^{\text {st }}$ century. Springer, New York, NY, p 431-484

Smith LM (2011) Impacts of spatial and temporal variation of water column production and respiration on hypoxia in Narragansett Bay. PhD thesis, University of Rhode Island, Narragansett, RI

Smith SV, Hollibaugh JT (1993) Coastal metabolism and the oceanic organic carbon balance. Rev Geophys 31: 75-89

Snooks JH, Jacobson JP, Kramer WP (1977) Summary of temperature and salinity observations in Block Island Sound during July 1975 through September 1976. New England Power Company/Yankee Atomic Electric Company, Westborough, MA

Staker RD, Bruno SF (1978a) An annual phytoplankton study in coastal waters off eastern Long Island (Block Island Sound). Bot Mar 21:439-450

Staker RD, Bruno SF (1978b) The phytoplankton of Block Island Sound: 1970-73. Nova Hedwigia 30:697-724

Strickland JDH, Parsons TR (1972) A practical handbook of 
seawater analysis. Fisheries Research Board of Canada, Ottawa

Stumpf RP, Arnone RA, Gould RW Jr, Martinolich PM, Ransibrahmanakul V (2003) A partially coupled oceanatmosphere model for retrieval of water-leaving radiance from SeaWiFS in coastal waters. In: Patt FS, Barnes RA, Eplee RE Jr, Franz BA and others (eds) Algorithm updates for the Fourth SeaWiFs data reprocessing. SeaWiFS Postlaunch Tech Rep Ser Vol 22, NASA Center for AeroSpace Information, Hanover, MD, p 51-74

Taft JL, Taylor R, Hartwig EO, Loftus R (1980) Seasonal oxygen depletion in Chesapeake Bay. Estuaries 3:242-247

Townsend DW, Keller MD, Sieracki ME, Ackleson SG (1992) Spring phytoplankton blooms in the absence of vertical water column stratification. Nature 360:59-62

Ullman DS, Codiga DL (2010) Characterizing the physical oceanography of coastal waters off Rhode Island, Part 2: New observations of water properties, currents, and waves. Rhode Island Ocean Special Area Management Plan Tech Rep 3, Rhode Island Coastal Resources Management Council, Wakefield, RI. www.crmc.ri.gov/samp_ ocean/finalapproved/TechRep03-PhysOcPart2-Ullman Codiga2010.pdf

Ullman DS, Codiga DL, Pfeiffer-Herbert A, Kincaid CR

Editorial responsibility: Steven Lohrenz,

New Bedford, Massachusetts, USA
(2014) An anomalous near-bottom, cross-shelf intrusion of slope water on the southern New England continental shelf. J Geophys Res 119:1739-1753

Walsh JJ (1988) On the nature of continental shelves. Academic Press, San Diego, CA

Watson DF (1992) Contouring: a guide to the analysis and display of spatial data. Pergamon Press, Oxford

Watson DF (1994) Nngridr: an implementation of natural neighbor interpolation. Natural Neighbor Series, Vol 1. David Watson, Claremont

Webb WL, Newton M, Starr D (1974) Carbon dioxide exchange of Alnus rubra: a mathematical model. Oecologia 17: 281-291

Williams RG (1969) The physical oceanography of Block Island Sound. US Navy Underwater Sound Laboratory, New London, CT

> Yoder JA, Kennelly MA (2003) Seasonal and ENSO variability in global ocean phytoplankton chlorophyll derived from 4 years of SeaWiFs measurements. Global Biogeochem Cycles 17:1112, doi:10.1029/2002GB001942

Yoder JA, Schollaert SE, O'Reilly J (2002) Climatological phytoplankton chlorophyll and sea surface temperature patterns in continental shelf and slope waters off the Northeast US coast. Limnol Oceanogr 47:672-682

Submitted: July 30, 2014; Accepted: June 5, 2015

Proofs received from author(s): August 24, 2015 